DE DE GRUYTER OPEN G

Mariusz Bednarek*

University of Social Sciences

Juan Carlos Neri Guzmán*

Polytechnic University of San Luis Potosi, Mexico
Journal of Intercultural Management

Vol. 6, No. 3, September 2014, pp. 211-242

DOI 10.2478/joim-2014-0031

\title{
Competitiveness factors of the candy industry in San Luis Potosí, México
}

\begin{abstract}
This paper is an attempt to analyze some of methodologies and models used to identify the most important factors to promote competitiveness on different levels: international, national, regional, industrial, and under a systemic and cluster approach. The purpose is to support the design of an appropriate model to analyze competitive performance of a local industry in Mexico, specifically the candy industry.

The results are useful to understand the areas of opportunity present in the candy industry and allow proposing strategic actions to promote competitiveness.

The goal of this article is to propose a strategic agenda to strengthen the competitiveness factor that makes the cluster approach distinctive among others, namely the role of actors and linking businesses.

This paper presents partial results of research of a doctoral thesis analyzing the case of the candy industry from the point of view of industrial clusters. The research is relevant considering that it presents a methodology for measuring the degree of functionality of a productive activity considered as "outstanding" in a local economy under international operation standards, which is not common in studies of developing countries.
\end{abstract}

Key words: $\mathrm{O} 25$ Industrial Policy; O38 Government Policy; $\mathrm{O} 43$ Institutions and Growth; C51 Model Construction and Estimation.

\section{Introduction}

One of the challenges of modern market economies, characterized by participating in international trading, is to produce quality goods and services with enough

*mb@eventgroup.pl; cster@gmail.com 
variety to be accepted in a medium and long-term horizon in different countries. Another challenge is to be capable of attracting foreign direct investment, being a mechanism enabling further investments and businesses that promote local development to be attracted. However, to achieve this, it is required to consolidate an adequate physical infrastructure and services in order to become attractive to international capital. This ability to keep a product on the market and attract investment is called competitiveness.

According to Grudzewski and Hejduk (2008) competitiveness is defined as the "capacity to face up to the competition of other entities, maintaining and increasing the market share as well as acquiring appropriate profits in relation to the foregoing".

In this sense, the term competitiveness relates to issues ranging from the micro to the macro scale, therefore it is necessary to entail the participation of many aspects and actors in the society to fulfill, in the broad sense, the requirements of competitiveness. Consequently, strengthening of an economy requires promoting development, at the same time, of individuals, enterprises, economic sectors, cities and territories, and thus coming out ahead in globalization and international capital movements.

On account of the generalized definition of competitiveness, different approaches have been developed, such that there is a methodology speaking of competitiveness in countries, another in regions, one for business, and even for individuals. Thus, competitiveness becomes a requirement not only for companies but also for individuals, institutions, cities and territories, so that competitiveness is an inter-related and interdependent responsibility. In this respect, Porter (2008) speaks of "new roles" for businesses, governments and institutions in general in an effort to improve competitiveness.

But what are the characteristics that a company, industry, city, country or individuals must meet to be seen as promoting competitiveness? These characteristics have been referred to as factors (determinants) of competitiveness which, once identified, may be the instruments by means of which productivity, growth and development is promoted.

The theoretical development to identify the determinants of competitiveness is extensive, and enriched every day. Adam Smith (1776) highlighted the role of specialization and division of labor. Alfred Weber (1909), for his part, recognized the advantages of agglomeration of businesses to reduce costs. Alfred Marshall (1919) emphasized the role of company linking to promote "industrial atmosphere". Rostow (1960) advocated the role of the industrial sector as a growth promoter. Schumpeter (1942) underlined the role of investment and infrastructure in the development, whereas Heckscher-Ohlin (1960) considered the role of comparative advantages in international trade as a principle through which all countries gain. Others recognized the role of education, technological development, public services etc. 
More recently, Michael Porter (1990) proposed a systematized theory (models) for business and supported the role of innovation, vertical-horizontal integration of businesses (among other aspects) as a strategy to come closer to competitiveness.

Now it is clear that in order to promote competitiveness, it is necessary to implement integrated policies promoting activities that improve the relationship between production companies, suppliers and customers and integrating them with value chains, taking advantage of the city's infrastructure and institutions to establish itself as a productive unit and assist in the creation of competitive territories, which is the challenge of modernity.

The objective of this paper is to show a proposal of research model that allows an analysis of the cluster as a factor of competitiveness and be implemented in a practical case in a local industry. The results allow defining strategic actions to promote competitiveness in the candy industry. The feature of this model is that it incorporates the most important factors of competitiveness considered in different theories to be implemented in economies like Mexico.

This article is divided into five sections, the first showing some of the most important methodologies for studying the factors of competitiveness; the second shows the model of cluster as a factor of competitiveness proposed to analyze the case of a local industry; the third section presents the main characteristics of the candy industry as a local case in San Luis Potosi, Mexico; the fourth presents the main results of competitiveness for local industry; the fifth section shows the proposed linkage between companies. Finally the conclusions and recommendations are shown.

\section{Focus of competitiveness factors}

Currently, there are different approaches applied to identify determinants of competitiveness, however, the difference between them is in the level of study: national, regional, industrial or business.

\section{Competitiveness on a national-international level}

The best known indexes applied to measure competitiveness on a country level are: the Global Competitiveness Index (GCI) published by the World Economic Forum and the World Competitiveness Yearbook by the Institute for Management Development. But there are also indicators of competitiveness identified in some countries, such as the one published by IMCO in Mexico or the European Competitiveness Report developed by the European Commission, among other methodologies.

\section{The World Competitiveness Yearbook}

The IMD World Competitiveness Yearbook (WCY) has been published since 1989. The WCY analyzes and ranks how nations and enterprises manage the total- 
ity of their competencies to achieve increased prosperity. This indicator considers not only the economic aspect (as GDP and productivity), but the political, social and cultural dimensions as well, and all of this recognizing that nations need to promote business environment with the most efficient structure, institutions and policies to encourage competitiveness of enterprises.

The 2013 WCY version comprises 60 economies, 4 factors, 20 sub-factors and over 300 competitiveness criteria based on research, economic literature, international, national and regional sources, and feedback from the business community, government agencies and academics. The countries are chosen because of their impact on the global economy and the availability of comparable international statistics. Furthermore, to calculate the reliable indicator, a network of 55 partner institutes has been established. Under this indicator, the disposition and quality of infrastructure in the country is very important for competitiveness (see Table 1).

According to the Institute for Management Development (IMD), competitiveness is defined as "the ability of a nation to create and maintain an environment that sustains more value creation for its enterprises and more prosperity for its people" (IMD 2013).

Table 1. Factors and sub-factors of competitiveness

\begin{tabular}{|l|l|}
\hline \multicolumn{1}{|c|}{ Factors } & \multicolumn{1}{c|}{ Sub-factors } \\
\hline $\begin{array}{l}\text { Economic Perfor- } \\
\text { mance } \\
(83 \text { criteria })\end{array}$ & $\begin{array}{l}\text { Macro-economic evaluation of the domestic economy: } \bullet \text { Domestic Econo- } \\
\text { my, } \bullet \text { International Trade, } \bullet \text { International Investment, } \bullet \text { Employment and } \bullet \\
\text { Prices. }\end{array}$ \\
\hline $\begin{array}{l}\text { Government Ef- } \\
\text { ficiency } \\
(70 \text { criteria })\end{array}$ & $\begin{array}{l}\text { Extent to which government policies are conducive to competitiveness: } \\
\text { Public Finance, } \bullet \text { Fiscal Policy, } \bullet \text { Institutional Framework, } \bullet \text { Business Legis- } \\
\text { lation and } \bullet \text { Societal Framework. }\end{array}$ \\
\hline $\begin{array}{l}\text { Business Efficiency } \\
(71 \text { criteria })\end{array}$ & $\begin{array}{l}\text { Extent to which the national environment encourages enterprises to per- } \\
\text { form in an innovative, profitable and responsible manner: } \bullet \text { Productivity } \\
\text { and Efficiency, } \bullet \text { Labor Market, } \bullet \text { Finance, } \bullet \text { Management Practices and } \bullet \\
\text { Attitudes and Values. }\end{array}$ \\
\hline $\begin{array}{l}\text { Infrastructure } \\
(114 \text { criteria) }\end{array}$ & $\begin{array}{l}\text { Extent to which basic, technological, scientific and human resources meet } \\
\text { the needs of business: } \bullet \text { Basic Infrastructure, } \bullet \text { Technological Infrastructure, } \\
\bullet \text { Scientific Infrastructure, } \bullet \text { Health and Environment and } \bullet \text { Education. }\end{array}$ \\
\hline
\end{tabular}

Source: IMD World Competitiveness Yearbook 2014

\section{The Global Competitiveness Index (GCI)}

The World Economic Forum defines national competitiveness as a "set of institutions, policies, and factors that determine the level of productivity of a country" (Schwab, 2014).

Since 2005, the World Economic Forum has based its competitiveness analysis on the Global Competitiveness Index (GCI), a comprehensive tool that measures the microeconomic and macroeconomic foundations of national competitiveness. The 2014-2015 GCI version is organized into three sub-indexes (Basic, Efficiency 
Enhancers and Sophistication Factors), each one being the key to a particular stage of development in a country. The index consists of 12 pillars and 114 sub-pillars, all of them identified as factors of competitiveness in several levels.

In the first stage (basic), the economy is factor-driven and countries compete based on their factor endowments, primarily on well-functioning institutions, infrastructure, macroeconomic environment and healthy workforce. The next step (efficiency enhancer) is distinguished for more efficient production processes and increase of product, which is supported by higher education, efficient market of goods, labor and finance, use of technologies and consolidated market. Finally, the last stage is characterized by its quality of life and a competitive business environment. This is because companies operate with a sophisticated production process, producing quality and innovative products, thereby generating high salaries. The competitiveness factors identified by GCI are detailed in Table 2.

Table 2. Basic, efficiency and innovation factors of competitiveness

\begin{tabular}{|c|c|}
\hline Group & Pillars and Sub-pillars \\
\hline \multirow[t]{4}{*}{ Basic } & $\begin{array}{l}\text { Institutions } \bullet \text { Property rights, } \bullet \text { Intellectual property protection, } \bullet \text { Diversion of public } \\
\text { funds, } \bullet \text { Public trust in politicians, } \bullet \text { Irregular payments and bribes, } \bullet \text { Judicial indepen- } \\
\text { dence, } \bullet \text { Favoritism in decisions of government officials, } \bullet \text { Wastefulness of government } \\
\text { spending, } \bullet \text { Burden of government regulation, } \bullet \text { Efficiency of legal framework in set- } \\
\text { tling disputes, } \bullet \text { Efficiency of legal framework in challenging regs., } \bullet \text { Transparency of } \\
\text { government policymaking, } \bullet \text { Business costs of terrorism, } \bullet \text { Business costs of crime and } \\
\text { violence, } \bullet \text { Organized crime, } \bullet \text { Reliability of police services, } \bullet \text { Ethical behavior of firms, } \\
\bullet \text { Strength of auditing and reporting standards, } \bullet \text { Efficacy of corporate boards, } \bullet \text { Pro- } \\
\text { tection of minority shareholders' interests, } \bullet \text { Strength of investor protection. }\end{array}$ \\
\hline & $\begin{array}{l}\text { Infrastructure } \bullet \text { Quality of overall infrastructure, } \bullet^{\bullet} \text { Quality of roads, } \bullet \text { Quality of rail- } \\
\text { road infrastructure, } \bullet \text { Quality of port infrastructure, } \bullet \text { Quality of air transport infra- } \\
\text { structure, } \bullet \text { Available airline seat } \mathrm{km} / \text { week, millions, } \bullet \text { Quality of electricity supply, } \\
\text { Mobile telephone subscriptions } / 100 \text { pop., }{ }^{\bullet} \text { Fixed telephone lines } / 100 \text { pop. } \\
\end{array}$ \\
\hline & $\begin{array}{l}\text { Macroeconomic environment } \bullet \text { Government budget balance, } \% \text { GDP, } \bullet \text { Gross national } \\
\text { savings, } \% \text { GDP, } \bullet \text { Inflation, annual } \% \text { change, } \bullet \text { General government debt, \% GDP, } \bullet \\
\text { Country credit rating, } 0-100 \text { (best). }\end{array}$ \\
\hline & $\begin{array}{l}\text { Health and primary education } \bullet \text { Malaria cases } / 100,000 \text { pop., } \bullet \text { Business impact of } \\
\text { malaria, } \bullet \text { Tuberculosis cases } / 100,000 \text { pop., } \bullet \text { Business impact of tuberculosis, } \bullet \\
\text { HIV prevalence, } \% \text { adult pop., } \bullet \text { Business impact of HIV/AIDS, } \bullet \text { Infant mortality, } \\
\text { deaths } / 1,000 \text { live births, } \bullet \text { Life expectancy, years, } \bullet \text { Quality of primary education, } \bullet \\
\text { Primary education enrollment, net } \% \text {. }\end{array}$ \\
\hline
\end{tabular}




\begin{tabular}{|c|c|}
\hline \multirow[t]{6}{*}{$\begin{array}{l}\text { Effi- } \\
\text { ciency } \\
\text { enhanc- } \\
\text { ers }\end{array}$} & $\begin{array}{l}\text { Higher education and training } \bullet \text { Secondary education enrollment, gross } \%, \bullet \text { Tertiary } \\
\text { education enrollment, gross } \%, \bullet \text { Quality of the education system, } \bullet \text { Quality of math } \\
\text { and science education, } \bullet \text { Quality of management schools, } \bullet \text { Internet access in schools, } \\
\text { Availability of research and training services, } \bullet \text { Extent of staff training. }\end{array}$ \\
\hline & $\begin{array}{l}\text { Goods market efficiency } \bullet \text { Intensity of local competition, } \bullet \text { Extent of market domi- } \\
\text { nance, } \bullet \text { Effectiveness of anti-monopoly policy, } \bullet \text { Effect of taxation on incentives to in- } \\
\text { vest, } \bullet \text { Total tax rate, } \% \text { profits, } \bullet \text { No. procedures to start a business, } \bullet \text { No. days to start } \\
\text { a business, } \bullet \text { Agricultural policy costs, } \bullet \text { Prevalence of trade barriers, } \bullet \text { Trade tariffs, } \% \\
\text { duty, } \bullet \text { Prevalence of foreign ownership, } \bullet \text { Business impact of rules on FDI, } \bullet \text { Burden } \\
\text { of customs procedures, } \bullet \text { Imports as a percentage of GDP, } \bullet \text { Degree of customer orien- } \\
\text { tation, } \bullet \text { Buyer sophistication. }\end{array}$ \\
\hline & $\begin{array}{l}\text { Labor market efficiency } \bullet \text { Cooperation in labor-employer relations, } \bullet \text { Flexibility of wage } \\
\text { determination, } \bullet \text { Hiring and firing practices, } \bullet \text { Redundancy costs, weeks of salary, } \\
\text { Effect of taxation on incentives to work, } \bullet \text { Pay and productivity, } \bullet \text { Reliance on profes- } \\
\text { sional management, } \bullet \text { Country capacity to retain talent, } \bullet \text { Country capacity to attract } \\
\text { talent, } \bullet \text { Women in labor force, ratio to men. }\end{array}$ \\
\hline & $\begin{array}{l}\text { Financial market development } \bullet \text { Availability of financial services, } \bullet \text { Affordability of } \\
\text { financial services, } \bullet \text { Financing through local equity market, } \bullet \text { Ease of access to loans, } \\
\text { Venture capital availability, } \bullet \text { Soundness of banks, } \bullet \text { Regulation of securities exchanges, } \\
\text { - Legal rights index, } 0-10 \text { (best). }\end{array}$ \\
\hline & $\begin{array}{l}\text { Technological readiness } \bullet \text { Availability of latest technologies, } \bullet \text { Firm-level technology } \\
\text { absorption, } \bullet \text { FDI and technology transfer, } \bullet \text { Individuals using Internet, } \%, \bullet \text { Fixed } \\
\text { broadband Internet subscriptions } / 100 \text { pop., } \bullet \text { Int'l Internet bandwidth, kb/s per user, } \bullet \\
\text { Mobile broadband subscriptions/100 pop. }\end{array}$ \\
\hline & $\begin{array}{l}\text { Market size } \bullet \text { Domestic market size index, } 1-7 \text { (best), } \bullet \text { Foreign market size index, } 1-7 \\
\text { (best), • GDP (PPP\$ billions), } \bullet \text { Exports as a percentage of GDP. }\end{array}$ \\
\hline \multirow[t]{2}{*}{$\begin{array}{l}\text { Innova- } \\
\text { tion and } \\
\text { sophis- } \\
\text { tication } \\
\text { factors }\end{array}$} & $\begin{array}{l}\text { Business sophistication } \bullet \text { Local supplier quantity, } \bullet \text { Local supplier quality, } \bullet \text { State of } \\
\text { cluster development, } \bullet \text { Nature of competitive advantage, } \bullet \text { Value chain breadth, } \bullet \text { Con- } \\
\text { trol of international distribution, } \bullet \text { Production process sophistication, } \bullet \text { Extent of mar- } \\
\text { keting, } \bullet \text { Willingness to delegate authority. }\end{array}$ \\
\hline & $\begin{array}{l}\text { Innovation } \bullet \text { Capacity for innovation, } \bullet \text { Quality of scientific research institutions, } \\
\text { Company spending on } \mathrm{R} \& \mathrm{D}, \bullet \text { University-industry collaboration in R\&D, } \bullet \text { Gov't pro- } \\
\text { curement of advanced tech products, } \bullet \text { Availability of scientists and engineers, } \bullet \text { PCT } \\
\text { patents, applications/million pop. }\end{array}$ \\
\hline
\end{tabular}

Source: Klaus Schwab. The Global Competitiveness Report 2014-2015: Full Data Edition. The World Economic Forum.

In contrast, the Mexican Institute for Competitiveness (IMCO) defines competitiveness as "the ability to attract and retain investment and talent." To calculate the Index of International Competitiveness, IMCO evaluates and compares the performance of the most important countries in the world in attracting and retaining talent and investment. The 2013 indicator was calculated by taking 46 countries into account on 10 indicators and 108 sub-indicators which had a significant impact on competitiveness. The IMCO highlights aspects such as the role of government, harnessing international relations and sustainable management of the environment (see Table 3). 
Table 3. International competitiveness factors and indicators

\begin{tabular}{|c|c|}
\hline Factors & Indicators \\
\hline $\begin{array}{l}\text { Reliable and } \\
\text { objective legal } \\
\text { system }\end{array}$ & $\begin{array}{l}\cdot \text { Corruption and good governance index, } \bullet \text { Informal economy index, } \bullet \text { Freedom } \\
\text { to compete, } \bullet \text { Index of civil liberties, } \bullet \text { Rule of law Index, } \bullet \text { Hacking index, } \bullet \\
\text { Property rights index, } \bullet \text { Average time to perform contracts, } \bullet \text { Index of judicial } \\
\text { independence, } \bullet \text { Index of impartiality of courts, } \bullet \text { Racketeering index. }\end{array}$ \\
\hline $\begin{array}{l}\text { Sustainable } \\
\text { management } \\
\text { of the environ- } \\
\text { ment }\end{array}$ & $\begin{array}{l}\cdot \text { Use of fertilizers in agriculture, } \bullet \text { Change in forest area, } \bullet \text { Protected areas, } \\
- \text { Relationship between production and consumption of water in agriculture, } \\
- \text { Recharge of aquifers, } \bullet \text { CO2 Emissions, } \bullet \text { Companies certified as ,clean', } \bullet \\
\text { Nonpolluting energy sources, } \bullet \text { Endangered Species, } \bullet \text { Ecological tragedies of } \\
\text { human intervention, } \bullet \text { Efficiency in water use, } \bullet \text { Creating wealth without con- } \\
\text { tamination. }\end{array}$ \\
\hline $\begin{array}{l}\text { Inclusive, ready } \\
\text { and healthy } \\
\text { society }\end{array}$ & $\begin{array}{l}\cdot \text { Life expectancy, } \bullet \text { Mortality in children under five, } \bullet \text { Dependents in relation } \\
\text { to the EAP, } \bullet \text { Human Development Index, } \bullet \text { Availability of drinking water per } \\
\text { capita, } \bullet \text { Number of years that a newborn will live in total health, } \bullet \text { Women the } \\
\text { EAP, } \bullet \text { Overall result of gender discrimination, } \bullet \text { Women in the legislature, } \bullet \\
\text { Illiteracy, } \bullet \text { Average schooling, } \bullet \text { EAP with undergraduate, } \bullet \text { Hospital beds. }\end{array}$ \\
\hline Stable economy & $\begin{array}{l}\cdot \text { Average growth of GDP, } \bullet \text { Variability of GDP growth, } \bullet \text { Consumer Price In- } \\
\text { dex, } \bullet \text { Variability of inflation growth, } \bullet \text { Government liabilities, } \bullet \text { External Debt, } \\
\bullet \text { Liquid reserves, } \bullet \text { Banking sector risk, } \bullet \text { Financial assets as } \% \text { of GDP. }\end{array}$ \\
\hline $\begin{array}{l}\text { Political sys- } \\
\text { tem stable and } \\
\text { functional }\end{array}$ & $\begin{array}{l}\bullet \text { Index of political stability, } \bullet \text { Corruption index, } \bullet \text { Of accountability index, } \bullet \\
\text { Electoral abstentionism, } \bullet \text { Military interference in rule of law and / or policy } \\
\text { process, } \bullet \text { Press Freedom Index, } \bullet \text { Influx of refugees, } \bullet \text { Index of political free- } \\
\text { dom. }\end{array}$ \\
\hline $\begin{array}{l}\text { Efficient mar- } \\
\text { ket factors }\end{array}$ & $\begin{array}{l}\cdot \text { Productivity of labor in manufacturing, } \bullet \text { Average labor productivity, } \bullet \text { EAP } \\
\text { whose salaries are negotiated by unions, } \bullet \text { Index of flexibility of labor laws, } \bullet \\
\text { Electricity generation, } \bullet \text { Energy sector liberalization, } \bullet \text { Rate of long-term loan of } \\
\text { banks, } \bullet \text { Discount rate for calculating investment, } \bullet \text { Productivity of fixed capital, } \\
\bullet \text { Mechanization of agriculture, } \bullet \text { Index of transparency and regulation of pri- } \\
\text { vate property, } \bullet \text { Workers in agriculture, } \bullet \text { Agricultural productivity per hectare. }\end{array}$ \\
\hline $\begin{array}{l}\text { Forerunner } \\
\text { sectors of } \\
\text { world class }\end{array}$ & $\begin{array}{l}\cdot \text { Coverage of fixed and mobile telephony, } \bullet \text { Internet Users, } \bullet \text { Investment in tele- } \\
\text { communications, } \bullet \text { Distance to the main export market, } \bullet \text { Scheduled passenger } \\
\text { flights, } \bullet \text { Index of port infrastructure, } \bullet \text { Intraurban transport of high capacity, } \bullet \\
\text { Density of railway network, } \bullet \text { Participation of the private financial system, } \bullet \text { In- } \\
\text { dex independence of the financial sector, } \bullet \text { Competition in banking, } \bullet \text { Extent to } \\
\text { which domestic banks face foreign competition, } \bullet \text { Liquidity in the stock market. }\end{array}$ \\
\hline $\begin{array}{l}\text { Efficient and } \\
\text { effective gov- } \\
\text { ernments }\end{array}$ & $\begin{array}{l}- \text { Index of difficulty of starting a business, } \bullet \text { Index of values favorable to com- } \\
\text { petitiveness, } \bullet \text { Time dedicated by senior executives to bureaucratic issues, } \bullet \text { Top } \\
\text { level of income tax }(\text { ISR) to the poorest, } \bullet \text { Additional } / \text { irregular payments as- } \\
\text { sociated with transactions, } \bullet \text { Visible importation costs, } \bullet \text { Corporate income tax, } \\
\bullet \text { Fiscal pressure index, } \bullet \text { Growth in public spending, } \bullet \text { Regulatory quality index, } \\
\cdot \text { Government effectiveness index, } \bullet \text { Promotion of competition, } \bullet \text { Cost of pay- } \\
\text { roll, } \bullet \text { Balanced budget, } \bullet \text { Expenditure on health, } \bullet \text { Expenditure on education, } \bullet \\
\text { Quality index of e-government, } \bullet \text { Transfers and subsidies. }\end{array}$ \\
\hline
\end{tabular}




\begin{tabular}{|l|l|}
\hline $\begin{array}{l}\text { Harnessing } \\
\text { international } \\
\text { relations }\end{array}$ & $\begin{array}{l}\bullet \text { Tourist arrivals, } \bullet \text { Tourism revenues, } \bullet \text { Index of economic openness, } \bullet \text { Number } \\
\text { of countries from which it imports more than } 50 \% \text { of the total, } \bullet \text { Hidden import } \\
\text { barriers, } \bullet \text { Number of countries to which it exports over } 50 \% \text { of the total, } \bullet \text { For- } \\
\text { eign direct investment (net), } \bullet \text { Access to foreign and domestic capital markets, } \\
\text { Military, } \bullet \text { Military expenditure, } \bullet \text { International organizations membership. }\end{array}$ \\
\hline $\begin{array}{l}\text { Innovation and } \\
\text { sophistication } \\
\text { of economic } \\
\text { sectors }\end{array}$ & $\begin{array}{l}\bullet \text { Value added in agriculture, } \bullet \text { Services }(\% \text { of GDP) }, \bullet \text { Coefficient of invention, } \\
\bullet \text { Income from royalties and licenses, } \bullet \text { Number of researchers, } \bullet \text { Number of } \\
\text { companies with ISO } 9000, \bullet \text { Expenditure on research and development, } \bullet \text { High } \\
\text { technology exports, } \bullet \text { National companies in the Forbes Global. }\end{array}$ \\
\hline
\end{tabular}

Source: International Competitiveness Index 2013. Mexican Institute for Competitiveness (IMCO).

\section{Competitiveness on the regional level}

While WEF's and IMD's reports are the two main methodologies for national competitiveness with global coverage, there are other reports and indexes targeted at specific macro-regions or groupings of countries. A good example is the European Competitiveness Index (Huggins and Davies, 2006) which selects and classifies indicators into four dimensions: "creative economy", "knowledge economy", "economic performance" and "infrastructure and accessibility". The central focus is the analysis of productivity growth as a key long-run driver of competitiveness. These indicators consider countries belonging to the European Union perceived as an economic region.

Regions are increasingly seen as natural units of economic analysis. It can be argued that an analysis of competitiveness on a regional level is particularly appropriate because, even more than nations, regions share infrastructure and access to institutions, being in direct competition for production factors (labor, capital and technology) (Camagni, 2002; Malecki, 2004).

In this sense, Lewis Dijkstra (2011) defines regional competitiveness as "the ability to offer an attractive and sustainable environment for firms and residents to live and work" (in respect of a region's capacity to provide attractive environment in both short and long term). The concept of regional competitiveness is ranked between micro and macro levels, which integrate the perspective of both businesses and residents.

There are interesting methodologies addressing competitiveness on the regional level, such as the European Regional Competitiveness Index (RCI), computed by the University of Wales Institute, based on the World Economic Forum's Global Competitiveness Index (GCI). The variables considered in this methodology are shown in Table 4. Some European countries also undertake dedicated efforts to develop national measures of regional competitiveness, such as in the UK (Huggins and Izushi, 2008), Croatia (UNDP, 2008), Lithuania (Snieška and Bruneckiené 2009), Poland (Bronisz, 2008) and Finland (Huovari, 2001). 
The novelty of competition policy on the regional level is that it takes the territorial unit into account as a basis for development planning, giving priority to the participation of business and local resources. On the regional level, the role of the society, infrastructure and telecommunications is strategic, naturally in addition to the productive one (Bronisz, 2008, Raluca, 2012).

Perhaps the clearest example of how important regions are in Europe is presented through the NUTS (Nomenclature of Units for Territorial Statistics) as a framework for development policies, assigning NUTS 1 to major socio-economic regions, NUTS 2 to basic regions for the application of regional policies, and NUTS 3 to small regions for specific diagnosis (Eurostat). More recently (December 2013), the European Union defined RIS3 (Research and Innovation Smart Specialization Strategy) as a growth strategy toward 2020 aimed to consolidate "smart, sustainable and inclusive" regional economies, characterized by high levels of employment, productivity and social cohesion.

Table 4. Factors of regional competitiveness

\begin{tabular}{|l|l|}
\hline Group & Pillars and Sub-pillars \\
\hline Basic & $\begin{array}{l}\text { Institutions } \bullet \text { Corruption, } \bullet \text { Rule of law, } \bullet \text { Government effectiveness, } \bullet \text { Voice and } \\
\text { accountability, } \bullet \text { Political stability, } \bullet \text { Regulatory quality, } \bullet \text { Control of corruption, } \\
\text { Ease of doing business, } \bullet \text { Property rights, } \bullet \text { Intellectual property protection, } \bullet \text { Ef- } \\
\text { ficiency of legal framework in settling disputes, } \bullet \text { Efficiency of legal framework in } \\
\text { challenging regulations, } \bullet \text { Transparency of government policymaking, } \bullet \text { Business } \\
\text { costs of crime and violence, } \bullet \text { Organized crime, } \bullet \text { Reliability of police services. }\end{array}$ \\
\cline { 2 - 3 } & $\begin{array}{l}\text { Infrastructure } \bullet \text { Motorway potential accessibility, } \bullet \text { Railway potential accessibility, } \\
\text { Number of passenger flights }\end{array}$ \\
\cline { 2 - 3 } & $\begin{array}{l}\text { Macroeconomic environment } \bullet \text { General government deficit/surplus, } \bullet \text { National sav- } \\
\text { ings, } \bullet \text { Inflation, } \bullet \text { Government bonds yield, } \bullet \text { Government debt. }\end{array}$ \\
\cline { 2 - 3 } & $\begin{array}{l}\text { Health and primary education } \bullet \text { Road fatalities, } \bullet \text { Healthy life expectancy, } \bullet \text { Infant } \\
\text { mortality, } \bullet \text { Cancer disease death rate, } \bullet \text { Heart disease death rate, } \bullet \text { Suicide death } \\
\text { rate. }\end{array}$ \\
\hline
\end{tabular}




\begin{tabular}{|c|c|}
\hline \multirow[t]{4}{*}{$\begin{array}{l}\text { Efficiency } \\
\text { enhancers }\end{array}$} & $\begin{array}{l}\text { Higher education and training } \bullet \text { Share of low-achieving } 15 \text {-year olds in reading, } \bullet \\
\text { Share of low-achieving } 15 \text {-year olds in math, } \bullet \text { Share of low-achieving } 15 \text {-year olds } \\
\text { in science, } \bullet \text { Population aged } 25 \text {-64 with higher educational attainment, } \bullet \text { Lifelong } \\
\text { learning, } \bullet \text { Accessibility of universities. }\end{array}$ \\
\hline & $\begin{array}{l}\text { Market size } \bullet \text { Disposable income per capita, } \bullet \text { Potential market size expressed in } \\
\text { GDP, } \bullet \text { Potential market size expressed in population. }\end{array}$ \\
\hline & $\begin{array}{l}\text { Labor market efficiency } \bullet \text { Employment rate (excluding agriculture), } \bullet \text { Long-term } \\
\text { unemployment, } \bullet \text { Unemployment rate, } \bullet \text { Labor productivity, } \bullet \text { Gender balance un- } \\
\text { employment, } \bullet \text { Gender balance employment, } \bullet \text { Female unemployment, } \bullet \text { NEET. }\end{array}$ \\
\hline & $\begin{array}{l}\text { Technological readiness } \bullet \text { Households with access to broadband, } \bullet \text { Individuals buy- } \\
\text { ing over internet, } \bullet \text { Household access to internet, } \bullet \text { Availability of latest technolo- } \\
\text { gies, } \bullet \text { Firm-level technology absorption, } \bullet \text { Technological adoption, } \bullet \text { FDI and tech- } \\
\text { nology transfer, } \bullet \text { Enterprises having purchased online (at least } 1 \%), \bullet \text { Enterprises } \\
\text { having received orders online (at least } 1 \%), \bullet \text { Enterprises with fixed broadband } \\
\text { access. }\end{array}$ \\
\hline \multirow{2}{*}{$\begin{array}{l}\text { Innovation } \\
\text { and sophis- } \\
\text { tication } \\
\text { factors }\end{array}$} & Business sophistication $\bullet$ Employment (K-N sectors), $\bullet$ GVA (K-N sectors). \\
\hline & $\begin{array}{l}\text { Innovation } \bullet \text { Total patent applications, } \bullet \text { Core Creativity Class employment, } \bullet \\
\text { Knowledge workers, } \bullet \text { Scientific publications, } \bullet \text { Total intramural R\&D expenditure, } \\
\bullet \text { Human Resources in Science and Technology }(\text { HRST), } \bullet \text { High-tech patents, } \bullet \text { ICT } \\
\text { patents, } \bullet \text { Eshare HT, } \bullet \text { Wshare HT. }\end{array}$ \\
\hline
\end{tabular}

Source: Annoni P. and Dijkstra L. EU Regional Competitiveness Index: RCI 2013. Joint Research Centre of the European Commission.

Some problems related to the indicators of regional competitiveness include the availability of information of the territorial units, indicators related to institutions, macroeconomic stability, quality of education, technological readiness of enterprises and venture capital.

\section{Competitiveness under a systemic approach}

An alternative way to study the competitiveness factors is provided by the systemic approach. This approach shows the most important components of competitiveness and represents their mutual relationships. The relevance of this systemic approach is that it also allows identifying the actors according to their level of involvement or responsibility in strengthening competitiveness.

Meyer-Stamer (2008) states the following: "We can define (systemic) competitiveness of a territory as the ability of a locality or region to generate high and rising incomes and improve livelihoods of the people living there."

The systemic approach methodology stresses the inclusion of competitiveness factors such as identity and strategic capacity of the actors in the region, presence of regional cluster, the existence of funds for financing, a model of national development and the principle of quality of life (see Table 5). 
Table 5. Some key factors determining Systemic Competitiveness on different levels of aggregation.

\begin{tabular}{|c|c|c|c|c|}
\hline & Supranational & National & Regional & Local \\
\hline Meta & $\begin{array}{l}\text { Competition be- } \\
\text { tween different types } \\
\text { of market economies. }\end{array}$ & $\begin{array}{l}\text { National develop- } \\
\text { ment model, national } \\
\text { innovation systems. }\end{array}$ & $\begin{array}{l}\text { Regional identity. } \\
\text { Strategic capacity of } \\
\text { regional actors. }\end{array}$ & $\begin{array}{l}\text { Local actors'ca- } \\
\text { pacity to co-oper- } \\
\text { ate, trust, innova- } \\
\text { tive milieu. }\end{array}$ \\
\hline Macro & $\begin{array}{l}\text { International finan- } \\
\text { cial markets. }\end{array}$ & $\begin{array}{l}\text { Macroeconomic } \\
\text { framework condi- } \\
\text { tions (e.g. tax system, } \\
\text { financial system). }\end{array}$ & $\begin{array}{l}\text { Solid budgetary } \\
\text { policy. } \\
\text { Investment capability } \\
\text { of government. }\end{array}$ & $\begin{array}{l}\text { Solid budgetary } \\
\text { policy. } \\
\text { Investment capa- } \\
\text { bility of govern- } \\
\text { ment. } \\
\text { Quality of life. }\end{array}$ \\
\hline Meso & $\begin{array}{l}\text { EU industrial policy. } \\
\text { EU technology } \\
\text { policy. } \\
\text { Montreal protocol. }\end{array}$ & $\begin{array}{l}\text { Promoting new tech- } \\
\text { nology, export pro- } \\
\text { motion, specialized } \\
\text { financing agencies. } \\
\text { Sectoral environ- } \\
\text { mental policy. }\end{array}$ & $\begin{array}{l}\text { Regional economic } \\
\text { development, technol- } \\
\text { ogy demonstration } \\
\text { centers, R\&D insti- } \\
\text { tutes, training institu- } \\
\text { tions, regional envi- } \\
\text { ronmental policy. } \\
\end{array}$ & $\begin{array}{l}\text { Local economic } \\
\text { development and } \\
\text { employment pro- } \\
\text { motion, training } \\
\text { institutions, incu- } \\
\text { bators, Chambers. }\end{array}$ \\
\hline Micro & $\begin{array}{l}\text { Transnational corpo- } \\
\text { rations. } \\
\text { Global commodity } \\
\text { chains. }\end{array}$ & $\begin{array}{l}\text { Medium-sized and } \\
\text { large corporations. } \\
\text { Dispersed networks. }\end{array}$ & $\begin{array}{l}\text { SME } \\
\text { Regional clusters. }\end{array}$ & $\begin{array}{l}\text { Locals cluster, lo- } \\
\text { cal subcontracting. }\end{array}$ \\
\hline
\end{tabular}

Source: Meyer, Jörg -Stamer (2008).

An interesting model used to recover and relate the factors favoring the regional competitiveness is the one referred to as a "regional competitiveness hat". The hat represents several layers: regional outcomes, regional outputs, regional throughputs and determinants of regional competitiveness. The determinants are shown as we move towards the crown of the hat, and return to the base to cope with the presence of external opportunities \& threats (see Figure 1).

The basic determinants of regional competitiveness are found at the bottom of the hat, in various rings around the productive cylinder. The production factors themselves (labor, capital and land) can be found in the first ring. Labor and land are less mobile and therefore more determined by regional factors. In the second ring, the primary factors of the regional investment climate can be found, namely infrastructure \& accessibility, human resources and productive environment (Martin, 2005).

There are also secondary factors, for instance institutions, internationalization, technology, demography, quality of place and environment. These determinants, such as "regions as hubs of knowledge", are related to the regional competitiveness like. The "regional competitiveness hat" includes some dynamic notions, including 
the influence exerted by global companies on the availability, price and quality of determinants.

Figure 1. The Regional Competitiveness Hat

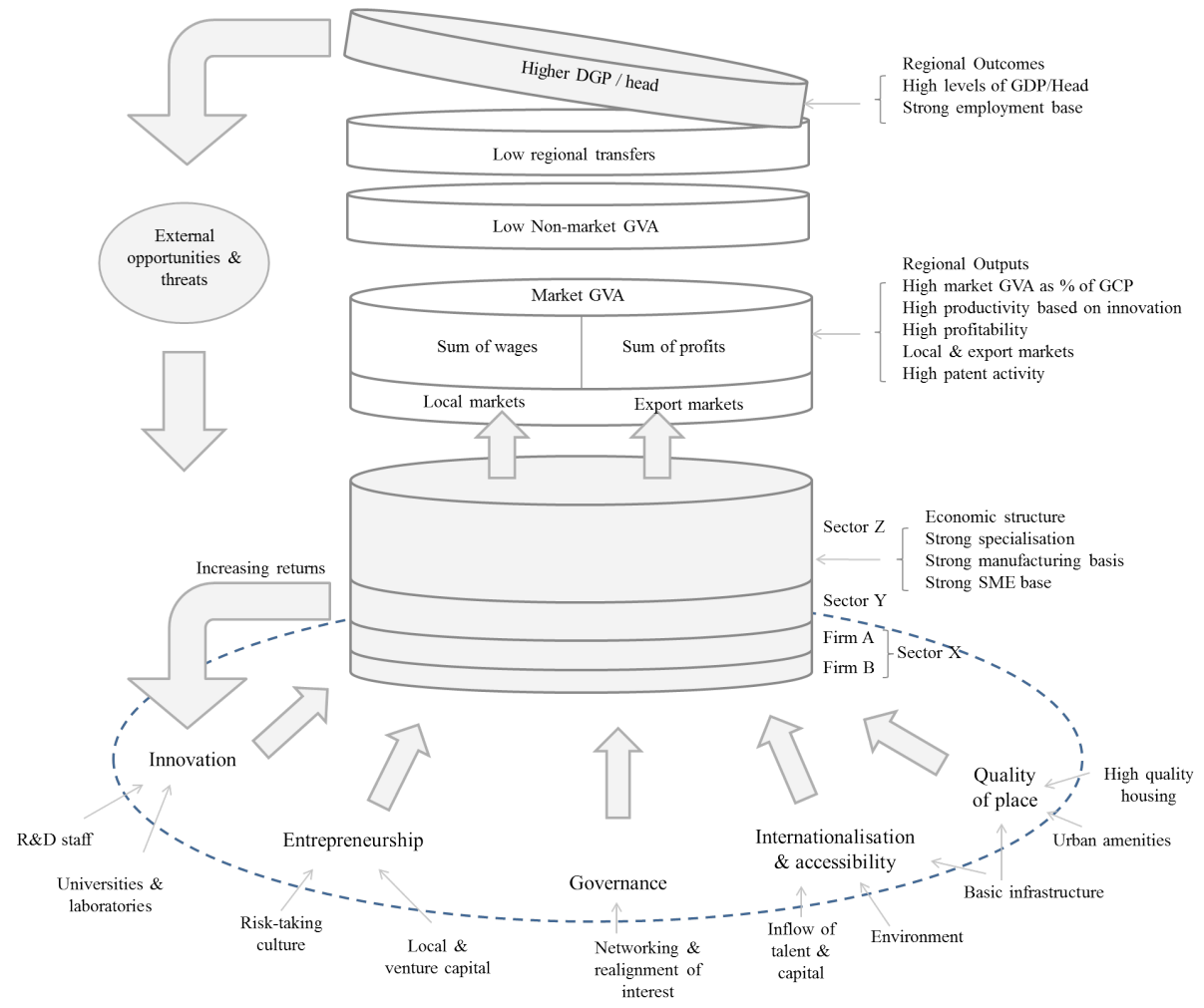

Source: Martin (2005). A Study on the Factors of Regional Competitiveness.

The Regional Competitiveness Hat also highlights the evolution in the competitiveness of enterprises towards industries which increase their specialization (economic structure), market share, productivity, profitability (regional outputs), consolidating the region with high levels of per capita production (regional outcomes), and favors an increase in the quality of life. On this level, the economy is able to face the threats and opportunities of the international market.

\section{Industrial-National Competitiveness}

The 2013 Global Manufacturing Competitiveness Index, edited by Deloitte Touche Tohmatsu Limited (Deloitte) and the U.S. Council on Competitiveness (Council), gathered information from more than 550 CEOs and senior manufacturing leaders of 38 countries in the world (39.7\% in North America, $28.5 \%$ in 
Asia, $21 \%$ in Europe, 5.4\% in South America and 5.4\% in Australia). This Index reflects how executives perceive the changes expected to occur in the manufacturing industry over the next five years and examines the forces driving the future of manufacturing, such as research, development, production, sales, distribution, logistics, customer service, marketing, support, only to mention the main ones, affecting competitiveness in the long term (see Table 6).

The 2013 Global Manufacturing Competitiveness Index defines 10 main drivers and 40 sub-components of competitiveness.

According to the U.S. Council of Competitiveness, "the key to U.S. prosperity in a global economy is to develop the most innovative workforce, educational system, and businesses that will maintain the United States' position as the global economic leader" (Council on Competitiveness, 2011).

Table 6. Drivers of global manufacturing competitiveness

\begin{tabular}{|c|c|}
\hline $\begin{array}{l}\text { Main driver/ } \\
\text { Component }\end{array}$ & Sub-component \\
\hline $\begin{array}{l}\text { Talent-driven in- } \\
\text { novation }\end{array}$ & $\begin{array}{l}\text { - Quality and availability of engineers, scientists and researchers; • Quality } \\
\text { and availability of labor; • Quality of primary and secondary schools to pro- } \\
\text { duce student population targeted in Science, Technology, Engineering and } \\
\text { Math (STEM); • Quality of college/university partnerships in research and } \\
\text { innovation; } \bullet \text { Effective and efficient immigration policies and processes to } \\
\text { attract and retain talent. }\end{array}$ \\
\hline $\begin{array}{l}\text { Cost and avail- } \\
\text { ability of labor } \\
\text { and materials }\end{array}$ & $\begin{array}{l}\text { - Cost competitiveness of material; } \bullet \text { Availability or raw material; } \bullet \text { Cost com- } \\
\text { petitiveness of wages; } \bullet \text { Cost competitiveness of labor other than wages. }\end{array}$ \\
\hline $\begin{array}{l}\text { Energy cost and } \\
\text { policies }\end{array}$ & $\begin{array}{l}\text { - Cost competitiveness of energy; } \bullet \text { Ongoing investments to improve and } \\
\text { modernize energy infrastructure; } \bullet \text { Comprehensive and effective energy } \\
\text { policy. }\end{array}$ \\
\hline Supplier network & $\begin{array}{l}\text { - Cost of competitiveness of local suppliers; } \bullet \text { Ability of the supply base to } \\
\text { innovate in products and processes; } \bullet \text { Financial stability and resources of the } \\
\text { supply base; } \bullet \text { Availability and responsiveness of qualified local supplier base. }\end{array}$ \\
\hline $\begin{array}{l}\text { Local business } \\
\text { dynamics }\end{array}$ & - Size and access to local market; • Intensity of local competition. \\
\hline $\begin{array}{l}\text { Economic, trade, } \\
\text { financial and tax } \\
\text { systems }\end{array}$ & $\begin{array}{l}\bullet \text { Tax rate burden and system complexity; } \bullet \text { Clarity and stability of regula- } \\
\text { tory, tax and economic policies; } \bullet \text { Health of economic and financial system; } \bullet \\
\text { Comprehensive and competitive trade policies; } \bullet \text { Central bank and economic } \\
\text { policies. }\end{array}$ \\
\hline $\begin{array}{l}\text { Quality of physi- } \\
\text { cal infrastructure }\end{array}$ & $\begin{array}{l}\text { - Quality and efficiency of electricity grid, information, technology (IT) and } \\
\text { telecom network; • Quality and efficiency of roads, ports, railways and air- } \\
\text { ports. }\end{array}$ \\
\hline
\end{tabular}




\begin{tabular}{|c|c|}
\hline $\begin{array}{l}\text { Government } \\
\text { investments in } \\
\text { manufacturing } \\
\text { and innovation }\end{array}$ & $\begin{array}{l}\cdot \text { Government emphasis on investments in science, technology, R\&D and } \\
\text { engineering; } \bullet \text { Collaboration between public and private sectors for long } \\
\text { term investments and national goals in manufacturing; } \bullet \text { National innovation } \\
\text { strategy that ensures robust pipeline from basic and applied research to full } \\
\text { commercialization; } \bullet \text { Long term predictable and steady support in govern- } \\
\text { ment sponsored science labs and national programs; } \bullet \text { Government support } \\
\text { to build capacity for manufacturing innovation (product and process); } \bullet \\
\text { Government investments in economic development through attraction of } \\
\text { manufacturing businesses. }\end{array}$ \\
\hline $\begin{array}{l}\text { Legal and regula- } \\
\text { tory system }\end{array}$ & $\begin{array}{l}- \text { Stability and clarity in legal and regulatory policies; } \bullet \text { Labor laws and regula- } \\
\text { tions; } \bullet \text { Regulatory compliance costs (health, safety, environment, tax, other); } \\
\text { - Intellectual property protection laws and enforcement; } \bullet \text { Legal and regula- } \\
\text { tory environment and enforcement; } \bullet \text { Antitrust laws and regulations. }\end{array}$ \\
\hline $\begin{array}{l}\text { Quality and avail- } \\
\text { ability of health- } \\
\text { care }\end{array}$ & $\begin{array}{l}\text { - Cost of of quality healthcare for employees and society; } \bullet \text { Regulatory poli- } \\
\text { cies (e.g. pollution, food safety) that are enforced to protect public health; } \bullet \\
\text { Quality, availability and access to healthcare professionals and facilities. }\end{array}$ \\
\hline
\end{tabular}

Source: 2013 Global Manufacturing Competitiveness Index

According to the Global Manufacturing Competitiveness Index, what weighs the most is the development of talents, suppliers, market regulation and disposition cost inputs as drivers of competitiveness.

\section{Competitiveness on national and industry level}

\section{Porter's Diamond}

Porter refers to a "nation's industry as internationally successful if it possessed competitive advantage relative to the best worldwide competitors" and recognizes that "the only meaning ful concept of competitiveness at the national level is productivity" (Porter, 1990).

In the context of international competition, competitive advantages for industrial groupings are determined by four components (or core drivers of competitive advantage): strategy and rivalry of the company, demand conditions, related industries, and factor conditions. The relationship between these components is represented by Porter's diamond. According to Porter, if these components are articulated in a continuous and systematic way, they lead to innovation and improvement of the entire system (see Table 7).

Table 7. Porter's Diamond and the determinants of national competitive advantage.

\begin{tabular}{|l|l|}
\hline $\begin{array}{l}\text { Strategy, } \\
\text { structure and } \\
\text { rivalry of the } \\
\text { company }\end{array}$ & $\begin{array}{l}\text { This component entails such aspects as } \bullet \text { possible entry of new producers, } \bullet \text { ri- } \\
\text { valry among competitors, } \bullet \text { government actions, } \bullet \text { policies designed as barriers } \\
\text { to entry or exit of firms, } \bullet \text { practices for product differentiation, } \bullet \text { rules and incen- } \\
\text { tives, } \bullet \text { type and intensity of local rivalry, } \bullet \text { investment promotion. It encourages } \\
\bullet \text { the labor market, } \bullet \text { encourages and regulates intellectual property, } \bullet \text { foreign } \\
\text { trade, } \bullet \text { foreign investment, } \bullet \text { sustained improvement. The degree of rivalry is a } \\
\text { function of the level of productivity of enterprises. }\end{array}$ \\
\hline
\end{tabular}




\begin{tabular}{|c|c|}
\hline $\begin{array}{l}\text { Demand } \\
\text { conditions }\end{array}$ & $\begin{array}{l}\text { Demand conditions analyze: } \bullet \text { the nature of local and international demand for } \\
\text { products or services of an industry, } \bullet \text { assessing issues such as market size, } \bullet \text { sup- } \\
\text { ply and demand, } \bullet \text { conditions of the selling process, } \bullet \text { price controls, } \bullet \text { physical } \\
\text { requirements policies, } \bullet \text { degree of demand sophistication, } \bullet \text { strong level of dif- } \\
\text { ferentiation, } \bullet \text { development of local markets. They identify and serve } \bullet \text { future } \\
\text { demands, } \bullet \text { entering of a new emerging market segment, } \bullet \text { attention from foreign } \\
\text { markets, etc. This gives access to the bargaining power with buyers in the pro- } \\
\text { cess of industrial integration. }\end{array}$ \\
\hline $\begin{array}{l}\text { Supporting } \\
\text { and related } \\
\text { industries }\end{array}$ & $\begin{array}{l}\text { This component takes the following into account: } \bullet \text { context of nature of support } \\
\text { industries, } \bullet \text { government level, } \bullet \text { educational and research institutions, } \bullet \text { related } \\
\text { industries, } \bullet \text { infrastructure, } \bullet \text { development of local suppliers. It promotes envi- } \\
\text { ronment of rivalry, attracts companies required in the industry, ensures presence } \\
\text { of clusters instead of isolated industries, leverages the advantages offered by the } \\
\text { location and concentration of businesses, among other. }\end{array}$ \\
\hline $\begin{array}{l}\text { Factor (Input) } \\
\text { Conditions }\end{array}$ & $\begin{array}{l}\text { Factors of production are the basic inputs to competition, they include: } \bullet \text { human } \\
\text { resources, } \bullet \text { financial, } \bullet \text { infrastructure provision, } \bullet \text { access to research centers and } \\
\text { technology, } \bullet \text { quality of the road network and public services, } \bullet \text { higher education } \\
\text { institutions, } \bullet \text { business organizations, } \bullet \text { administrative infrastructure, } \bullet \text { scientific } \\
\text { and technological infrastructure, } \bullet \text { natural resources, } \bullet \text { legal system updated, } \bullet \\
\text { flexibility in the regulatory system, } \bullet \text { information infrastructure. }\end{array}$ \\
\hline
\end{tabular}

Source: Porter (2008)

Porter's diamond model is seen as a function of specialized and advanced factors of production, sophisticated demand, intense rivalry and varied strategies among businesses, and finally, the existence of supplying and related industries. Likewise, Porter acknowledges that the determinants of competitiveness are affected by two aspects: government policy and changes taking place abroad, for example, the world's technological change, wars and natural disasters or promotion of innovation by the government.

Some competitiveness factors which stand out in Porter's model include vertical and horizontal integration, innovation, creation of added value, development of suppliers etc. which can be distinguished as business strategies functioning among companies.

\section{Competitiveness in the cluster model}

While competitiveness is a goal, Porter's proposals laid modern foundations for the development of cluster policies as a strategy to consolidate both industries and competitive regions. Porter's diamond model, as shown above, defines business strategies for companies and industries to achieve sustained competitiveness in international markets.

According to Porter (2008), clusters can be defined as follows: "Geographic concentrations of interconnected companies, specialized suppliers, service providers, firms in related industries, and associated institutions (for example, universities, agencies of standards, and trade 
associations) in particular fields that compete but also cooperate. Critical masses of unusual competitive success, in particular business areas, clusters are a striking feature of virtually every national, regional, state and even metropolitan economy, especially those of more economically advanced nations".

A good representation of a cluster is presented in the funnel model, which identifies four major components (Sölvell, 2003)"

- The general business environment within a nation, which comprises aspects such as national legacy and culture, geographical position, general institutions and legal framework, and the macroeconomic environment;

- The microeconomic business environment, which takes Porter's diamond model into account: context for business strategy and rivalry, demand conditions, related and supporting industries, factor (input) conditions;

- Participation of actors (cluster). Linking between industries, government, academia (higher education institutions and technology transfer centers), finance and institutions enabling collaboration;

- Design of policy (regional-industry-SME, FDI attraction, science-researchinnovation).

A funnel model-based cluster recognizes that quality of the business environment of a country depends on the degree of consolidation and dynamism among its major components. When this happens, the economy evolves and companies achieve greater participation in foreign markets, and thereby the competitiveness increases (see Figure 2).

Figure 2. Business environment in a cluster - the funnel model.

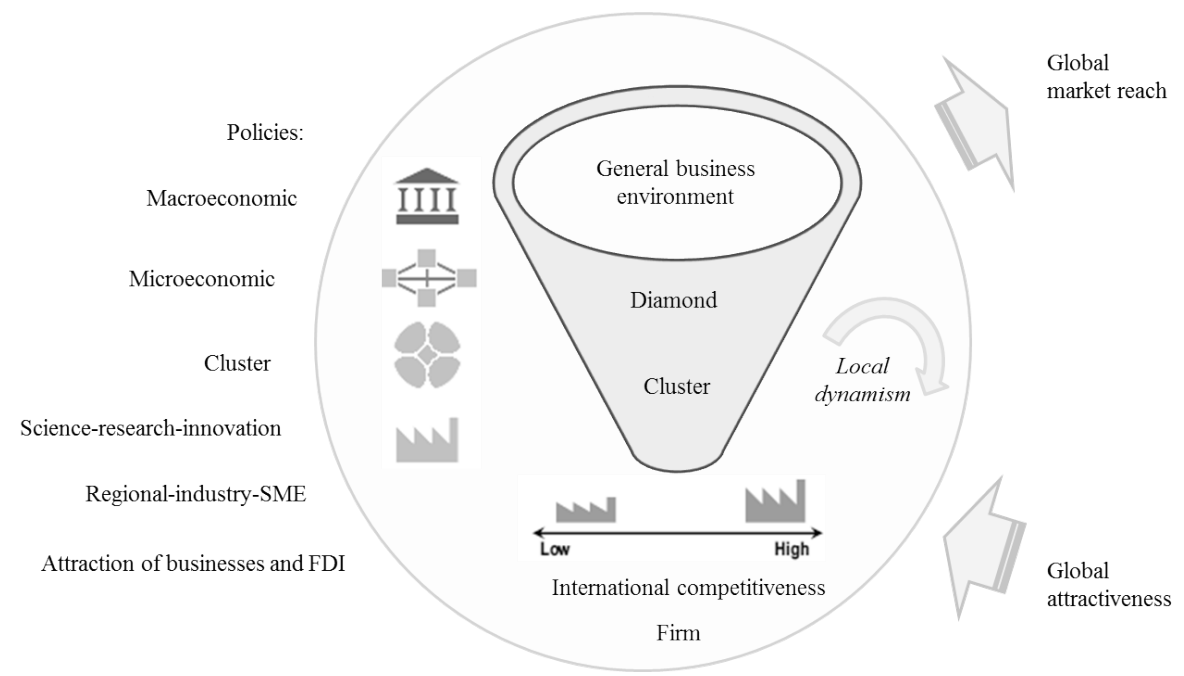

Source: Sölvell (2003) 
This particular model attaches very high importance to the role of collaboration (cluster or actors in Figure 2) as a strategy for companies to benefit from external economies and economies within reach, so they can achieve their goals of productivity and competitiveness with less effort, at lower cost, in less time and with greater certainty of success. In this sense, collaboration becomes the most important business strategy in a cluster policy.

\section{Competitiveness of a local industry according to the cluster approach}

As we have seen, competitiveness is represented by a set of multisectoral factors, which altogether make it possible to recreate a living environment in which business and industry can develop their productive capacities and reflect them through the generation of investment, benefits, jobs, higher wages, exports, environmental protection, quality products, etc.

It is commonly agreed under different theoretical approaches to the notion of competitiveness that if there is a healthy competitive (in quality, cost, innovation and price) business environment (regulated and featuring incentives), the result will be steady development characterized by high expectations of growth for companies and citizens with high quality of life.

The study discussed in this paper has reviewed some of the most important factors of competitiveness promotion (related to the industry, the region and mainly to the cluster) with the purpose of developing a model to measure the impact of competitiveness factors on an important local industry. The results of this research will allow for proposing activities aimed to increase the competitiveness of the local candy sector through development of industrial clusters, and for defining recommendations pertaining to industries of a similar type for other states in Mexico.

Research confirms that clusters are promoters of competitiveness for companies owing to the factors that promote them, and these clusters can be established in different production sectors, under different conditions of economic activity, and implemented in different countries. The purpose of this study is to propose an alternative way to examine economic activities in order to identify the factors that will allow these activities to operate in a more efficient and competitive way through application of the industrial cluster approach.

\section{Model of competitiveness factors for a local economy}

The analysis of competitiveness factors for industrial clustering is performed by means of five major components: 1) industry structure, 2) product sale, distribution and expectation of the product, 3) integration of actors, 4) product characteristics and 5) activity status trends (macroeconomic stability). These components are broken into 20 indicators, using a total of 56 variables. Each variable is calculated in a particular way and made comparable through a statistical process of standardization. Variables are grouped as shown in Table 8. 
The model considers a total of 56 variables, 44 of which are categorized as soft data extracted from surveys (79\%), and 12 have been put under the category of hard data acquired from official institutions (21\%). The questionnaire by means of which information was collected in companies includes three types of variables: nominal, dichotomous and a scale which uses numeric values (absolute or percentage) and Likert intervals ( 3 and 5 ranges). This information has been supplemented by statistical information, interviews, field studies and other field work.

\section{Table 8. Model of competitiveness factors for a local economy}

\begin{tabular}{|c|c|}
\hline Component & Related variables \\
\hline $\begin{array}{l}\text { Industry } \\
\text { Structure }\end{array}$ & $\begin{array}{l}- \text { Participation of companies in the industry, } \bullet \text { Industrial concentration, } \bullet \text { Represen- } \\
\text { tativeness in the productive chain, } \bullet \text { Historic reference in the productive chain, } \bullet \\
\text { Origin of enterprises, } \bullet \text { Participation in the economic sector, } \bullet \text { Modernization level, } \\
\bullet \text { Investment level, } \bullet \text { Technological level, } \bullet \text { Machinery and equipment investment, } \bullet \\
\text { Changes in the organization of production, } \bullet \text { Knowledge of the productive chain, } \\
- \text { Trust in suppliers and clients, } \bullet \text { Time of relationship with suppliers and clients, } \\
- \text { Standard in inputs and services, } \bullet \text { Development of networks of collaboration, } \bullet \\
\text { Knowledge of the market, } \bullet \text { Tendencies of the market, } \bullet \text { Products, prices and de- } \\
\text { mand expectations, } \bullet \text { Knowledge of the industry, } \bullet \text { Interest in participation. }\end{array}$ \\
\hline $\begin{array}{l}\text { Product } \\
\text { realization }\end{array}$ & $\begin{array}{l}\cdot \text { Origin and size of clients, } \bullet \text { Type of product commercialization, } \bullet \text { Cost of com- } \\
\text { mercialization, } \bullet \text { Strategy of sales, } \bullet \text { Participation in investment, } \bullet \text { Prices and mar- } \\
\text { ket stability, } \bullet \text { Expectations of market stability. }\end{array}$ \\
\hline $\begin{array}{l}\text { Integration } \\
\text { of actors }\end{array}$ & $\begin{array}{l}\bullet \text { level of cooperation and competition among companies, } \bullet \text { Integration and finan- } \\
\text { cial support, } \bullet \text { Government support, } \bullet \text { Technical assistance and professional ser- } \\
\text { vices, } \bullet \text { Universities and research centers for collaboration, } \bullet \text { Formation of collabo- } \\
\text { ration networks, } \bullet \text { Promotion and information activities, } \bullet \text { Participation in related } \\
\text { events, } \bullet \text { Integration requirements. }\end{array}$ \\
\hline $\begin{array}{l}\text { Product } \\
\text { character- } \\
\text { istics }\end{array}$ & $\begin{array}{l}\cdot \text { Product price trends, } \bullet \text { Analysis of participation in consumption, } \bullet \text { Export index, } \\
\bullet \text { Diversification of markets, } \bullet \text { Level of preference in the brand, } \bullet \text { Origin of innova- } \\
\text { tion, } \bullet \text { Preference level for the substitute item, } \bullet \text { Sources of innovation, } \bullet \text { Develop- } \\
\text { ment of new products, } \bullet \text { Percentage of investment in advertising, } \bullet \text { Competition } \\
\text { index, } \bullet \text { Index of quality for a chain link, } \bullet \text { Customer satisfaction, } \bullet \text { Practices of the } \\
\text { competition. }\end{array}$ \\
\hline $\begin{array}{l}\text { Activity } \\
\text { status trends }\end{array}$ & $\begin{array}{l}\bullet \text { Diagnostics of trends in the industrial sector and its expectations, } \bullet \text { Analysis of } \\
\text { the competitive arena, } \bullet \text { Analysis of the Diamond, } \bullet \text { Trend in main macroeconomic } \\
\text { variables related to the sector: } \\
{[\bullet \text { Budget deficit, } \bullet \text { Scale of payments (foreign debt); } \bullet \text { Inflation, } \bullet \text { Investment (capi- }} \\
\text { tal), } \bullet \text { Growth, } \bullet \text { Income distribution, } \bullet \text { Exports] } \bullet \text { Strengthening internal capacity } \\
\text { of companies, } \bullet \text { Analysis of customer preferences and product characteristics. }\end{array}$ \\
\hline
\end{tabular}

Source: author's elaboration.

A graphical way of representing the model is shown in Figure 
Figure 3. Cluster model to measure the factors that promote competitiveness.

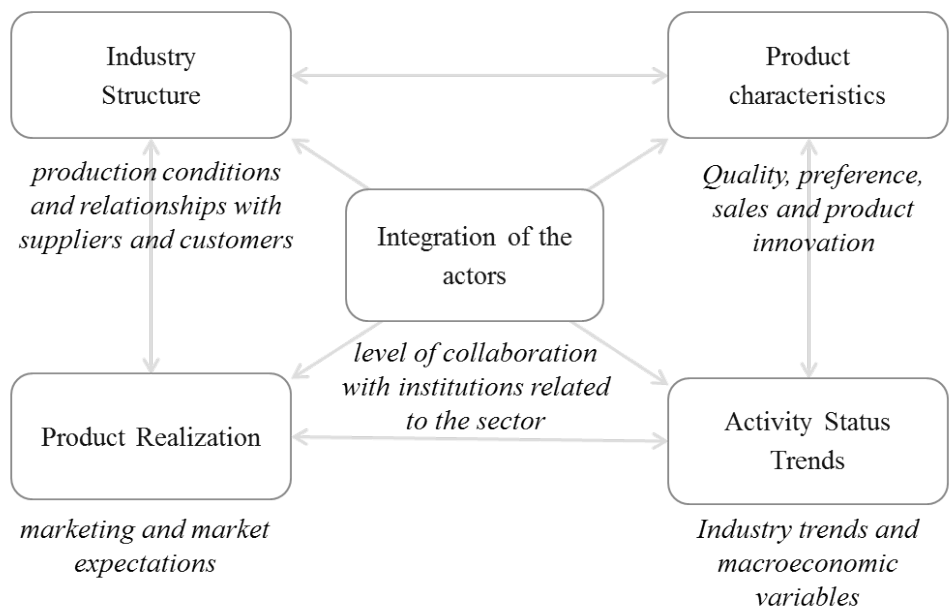

Source: author's elaboration

\section{The candy industry in San Luis Potosi, Mexico}

\section{San Luis Potosi, Mexico}

The land area of San Luis Potosi is $62.305 \mathrm{~km}^{2}$. The geographic position and the available road infrastructure enables San Luis Potosí to be a strategic center of trade, business, transportation, distribution of goods, and a reference area for access to the country's largest markets: Mexico City $(424 \mathrm{~km})$, Monterrey $(537 \mathrm{~km})$ and Guadalajara $(354 \mathrm{~km}$ ). These cities altogether concentrate $25 \%$ of the country's population. There is also access to intermediate markets of Matamoros $(658 \mathrm{~km})$, Aguascalientes $(168 \mathrm{~km})$, León $(183 \mathrm{~km})$, Querétaro $(202 \mathrm{~km})$, Saltillo $(443 \mathrm{~km})$, Tampico $(426 \mathrm{~km})$, Zacatecas $(192 \mathrm{~km})$ as well as the city of Manzanillo $(666 \mathrm{~km})$. Additionally, highways connect San Luis Potosí with U.S. cities such as Laredo (750 km), San Antonio (991 km), Dallas $(1,432 \mathrm{~km})$ and Houston $(1,311 \mathrm{~km})$ where a considerable share of foreign trade takes place.

The highway to Mexico City is linked with Plan Puebla-Panama which connects both tourist and commercial land routes to Central America. Equally important is the highway between San Luis Potosí and Manzanillo-Tampico, connected with the Gulf of Mexico, thus joining the Pacific Ocean ports and providing for passage of goods imported and/or exported to different continents. The railway line extends for 1,247 km across San Luis Potosí and features its own Intermodal Terminal (interport), with on-site logistics services and customs house, operating under the new Strategic Bonded Warehouse customs regime. 
In San Luis Potosí, the manufacturing industry is the main economic activity (corresponding to $63 \%$ of gross total production). The most important sub-sectors within the manufacturing industry are: basic metal, transport equipment manufacturing, food and electric power equipment, contributing $24.4 \%, 17 \%, 15 \%$ and $12.8 \%$ of gross total production in this sector, respectively. San Luis Potosí is one of 10 (of 32) units in Mexico where the food industry is highly specialized, therefore it is representative of this sector.

Among the industries expected to grow in Mexico there is the food industry, being one of six strategic sectors to promote competitiveness in Mexico, and furthermore, in six years, Mexico will be producing $75 \%$ of the food consumed by its inhabitants. The country is also the second largest food supplier of the United States and the third largest in continental America, all of which makes the food industry a promising sector (ProMéxico, 2011)

\section{The candy industry of Mexico}

This study focuses on the candy industry, considering the fact that it is the third most important economic activity in the food industry. It also represents an area of opportunity, because $75 \%$ of states in Mexico have food clusters, but none functioning in the candy industry (ITESM, 2012).

In Mexico, the production of candy is mainly concentrated in 6 of 32 Mexican states, which generates over $80 \%$ of total production. This means that certain regions of the country are specialized in this activity. Cities with an important economic profile in candy production are: Jalisco, Puebla, Mexico City, San Luis Potosi and Estado de Mexico, but there are also federal entities where important companies are based, such as Quintana Roo, Chihuahua, Nuevo Leon and Michoacán.

Figure 4 illustrates the entities of Mexico according to the level of candy production, which shows that the Central-West region of the country, where San Luis Potosi is located, is the most important one in terms of this activity.

The candy market in Mexico integrates both large international companies and important local companies spread across different regions. Among those operating in San Luis Potosi, there are Canel's and Ricolino as international companies, but important local businesses, such as Costanzo and La Frontera are also present. A similar situation is observed in other entities.

Another important aspect of the candy industry is the role of medium and large enterprises. Figure 5 shows that the role of medium and large companies in Mexican economic sectors, including the candy industry, is more important than in the food industry. For example, $57 \%$ of jobs created in the candy industry are provided by large firms, while medium firms only contribute in $20 \%$, whereas the remaining 23\% is attributed to micro and small enterprises. However, the most important characteristic of the candy industry is that $95 \%$ of companies are micro and small 
enterprises, but they generate merely $7.4 \%$ of gross production. Meanwhile, only $3.4 \%$ of businesses operating in the candy industry are medium-sized, but they employ $20 \%$ of workers and generate $16.4 \%$ of production in this sector.

Figure 4. Entities of Mexico according to their contribution to the candy industry production
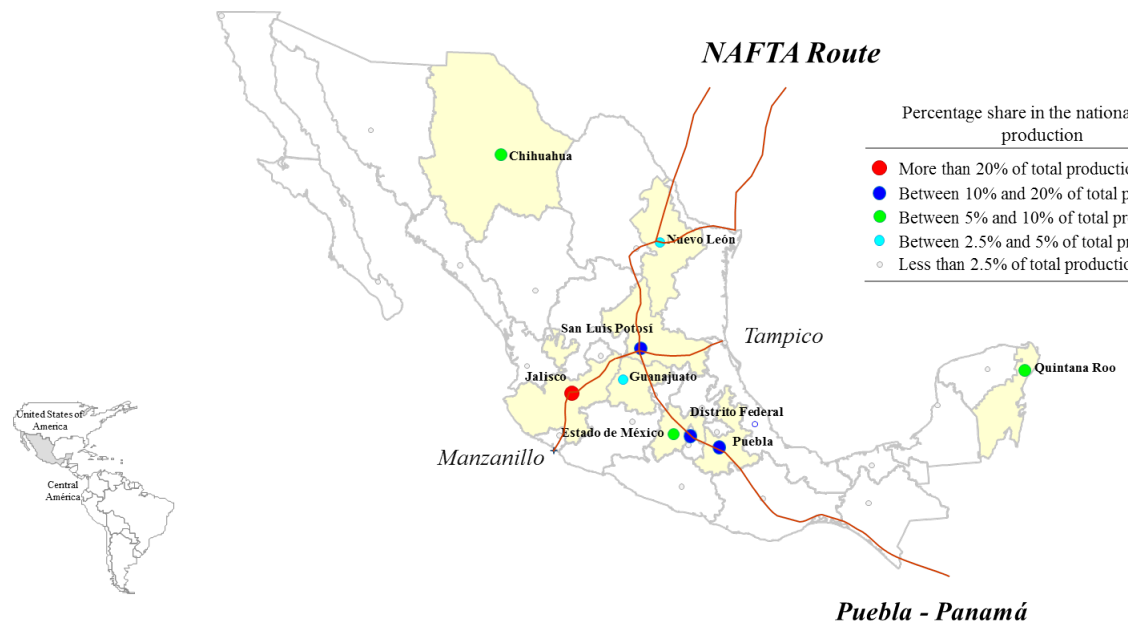

Source: author's elaboration based on INEGI, Censos Economicos 2009

Figure 5. Contribution of enterprises to the jobs created according to size (\%)

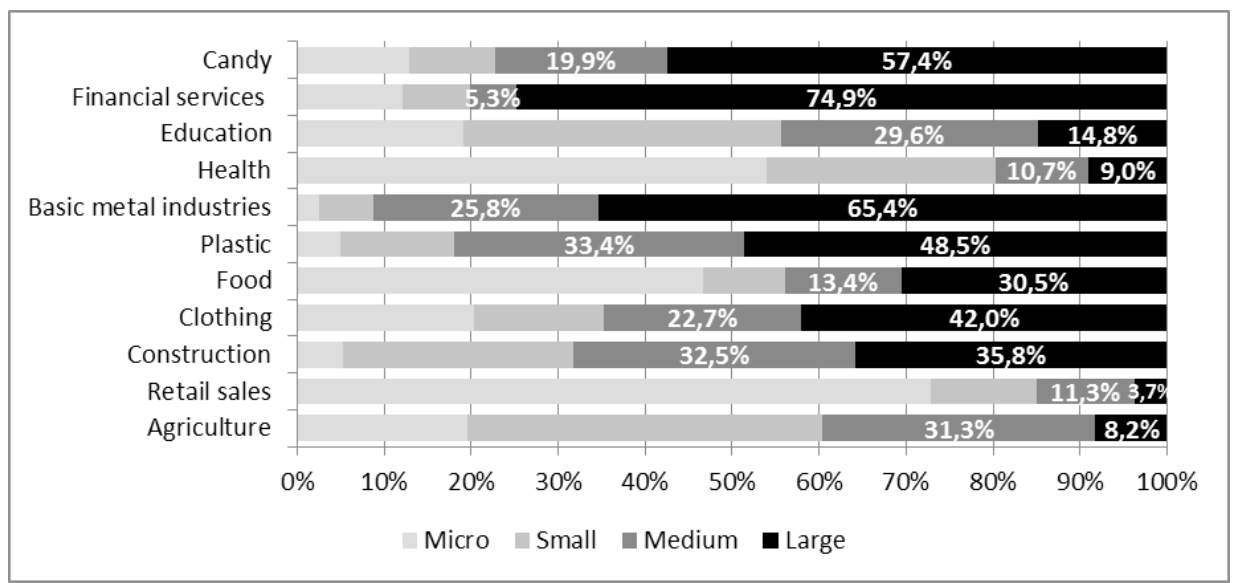

Source: author's elaboration based on INEGI, Censos Economicos 2009

Table 9 shows the relevance of medium and large companies operating in the candy industry in the most specialized entities in this sector. Thus, while nationally 
the percentage of medium-size and large companies is $5.1 \%$, in all specialized entities this percentage is higher, for example, the level of $12.7 \%$ is reached in San Luis Potosi. Similarly, in terms of jobs created, medium-size and large companies of the candy industry generated $77.3 \%$, while in states such as Jalisco and San Luis Potosi, i.e. ones specialized in this sector, they contributed to over $90 \%$ of jobs created. As regards production in the candy industry, while medium-size and large companies account for $92 \%$ of national production, in specialized entities in this sector, such as Puebla and San Luis Potosi, the contribution exceeds 92\%.

As shown in Table 9, the relevance of small and medium-size enterprises (between 10 and 250 employees), which are usually local companies consolidated throughout years and reaching the SME scale, is considerable, as they constitute $23.8 \%$ of businesses, generate $21.2 \%$ of jobs and contribute to total production in the candy industry in San Luis Potosi in $7.3 \%$. Therefore, its role in the economy is significant, and for this reason, it is necessary to implement policies that will increase competitiveness and consolidate them in the local and international market.

Table 9. Micro, small, medium-size and large companies in major production entities of the candy industry according to share in the total number of businesses, employment and output generated.

Percentage of companies according to size in specialized federal entities

\begin{tabular}{c|c|c|c|c|c|c}
\hline $\begin{array}{c}\text { Company } \\
\text { size }\end{array}$ & National & Puebla & Jalisco & $\begin{array}{c}\text { Distrito } \\
\text { Federal }\end{array}$ & $\begin{array}{c}\text { San Luis } \\
\text { Potosi }\end{array}$ & $\begin{array}{c}\text { Estado de } \\
\text { Mexico }\end{array}$ \\
\hline Micro & $84.9 \%$ & $86.4 \%$ & $71.8 \%$ & $75.7 \%$ & $71.4 \%$ & $82.1 \%$ \\
Small & $10.0 \%$ & $7.4 \%$ & $19.0 \%$ & $15.1 \%$ & $15.9 \%$ & $11.1 \%$ \\
Medium & $3.4 \%$ & $2.5 \%$ & $6.7 \%$ & $6.8 \%$ & $7.9 \%$ & $4.3 \%$ \\
Large & $1.7 \%$ & $3.7 \%$ & $2.5 \%$ & $2.4 \%$ & $4.8 \%$ & $2.6 \%$ \\
Total & $100.0 \%$ & $100.0 \%$ & $100.0 \%$ & $100.0 \%$ & $100.0 \%$ & $100.0 \%$ \\
\hline
\end{tabular}

Percentage of jobs created according to size of companies in specialized federal entities

\begin{tabular}{c|c|c|c|c|c|c}
\hline $\begin{array}{c}\text { Company } \\
\text { size }\end{array}$ & National & Puebla & Jalisco & $\begin{array}{c}\text { Distrito } \\
\text { Federal }\end{array}$ & $\begin{array}{c}\text { San Luis } \\
\text { Potosi }\end{array}$ & $\begin{array}{c}\text { Estado de } \\
\text { Mexico }\end{array}$ \\
\hline Micro & $12.8 \%$ & $6.1 \%$ & $7.5 \%$ & $10.3 \%$ & $4.8 \%$ & $9.5 \%$ \\
Small & $9.9 \%$ & $2.2 \%$ & $9.8 \%$ & $14.1 \%$ & $5.0 \%$ & $9.2 \%$ \\
Medium & $19.9 \%$ & $8.9 \%$ & $22.0 \%$ & $30.7 \%$ & $16.2 \%$ & $18.0 \%$ \\
Large & $57.4 \%$ & $82.8 \%$ & $60.7 \%$ & $44.9 \%$ & $74.0 \%$ & $63.3 \%$ \\
Total & $100.0 \%$ & $100.0 \%$ & $100.0 \%$ & $100.0 \%$ & $100.0 \%$ & $100.0 \%$ \\
\hline
\end{tabular}

Share of production output according to size of companies in specialized federal entities

\begin{tabular}{c|c|c|c|c|c|c}
\hline $\begin{array}{c}\text { Company } \\
\text { size }\end{array}$ & National & Puebla & Jalisco & $\begin{array}{c}\text { Distrito } \\
\text { Federal }\end{array}$ & $\begin{array}{c}\text { San Luis } \\
\text { Potosi }\end{array}$ & $\begin{array}{c}\text { Estado de } \\
\text { Mexico }\end{array}$ \\
\hline
\end{tabular}




\begin{tabular}{ccccccc}
\hline Micro & $1.6 \%$ & $0.4 \%$ & $1.5 \%$ & $1.7 \%$ & $0.5 \%$ & $1.6 \%$ \\
Small & $5.8 \%$ & $0.5 \%$ & $4.5 \%$ & $8.3 \%$ & $0.9 \%$ & $19.8 \%$ \\
Medium & $16.4 \%$ & $0.7 \%$ & $18.4 \%$ & $18.0 \%$ & $6.4 \%$ & $15.2 \%$ \\
Large & $76.2 \%$ & $98.4 \%$ & $75.6 \%$ & $72.0 \%$ & $92.2 \%$ & $63.4 \%$ \\
Total & $100.0 \%$ & $100.0 \%$ & $100.0 \%$ & $100.0 \%$ & $100.0 \%$ & $100.0 \%$ \\
\hline
\end{tabular}

Source: author's elaboration based on INEGI, Censos Economicos 2009

\section{Candy industry and competitiveness factors}

The research results show that competitiveness factors of the candy industry are at a moderate level of consolidation. Figure 6 shows that among the five components of the cluster model, only one reaches a high level of performance, 3 attain a moderate level and 1 - low level.

The component that displays high-performance competitiveness relates to product characteristics, which indicates that competitiveness factors such as product quality, preference for local products, product price trends, development of new products, have all been positively consolidated in general.

To the contrary, the component showing lesser competitiveness is the "integration of the actors" which includes factors such as integration and collaborative work between companies and suppliers, customers, government, universities, financial institutions, business support organizations and institutions in general. This indicator is particularly important, because in this model, cluster collaboration is an important business strategy applied to achieve objectives in a shorter time, at lower costs and with higher certainty.

Figure 6. Performance levels of the cluster model components for the candy industry.

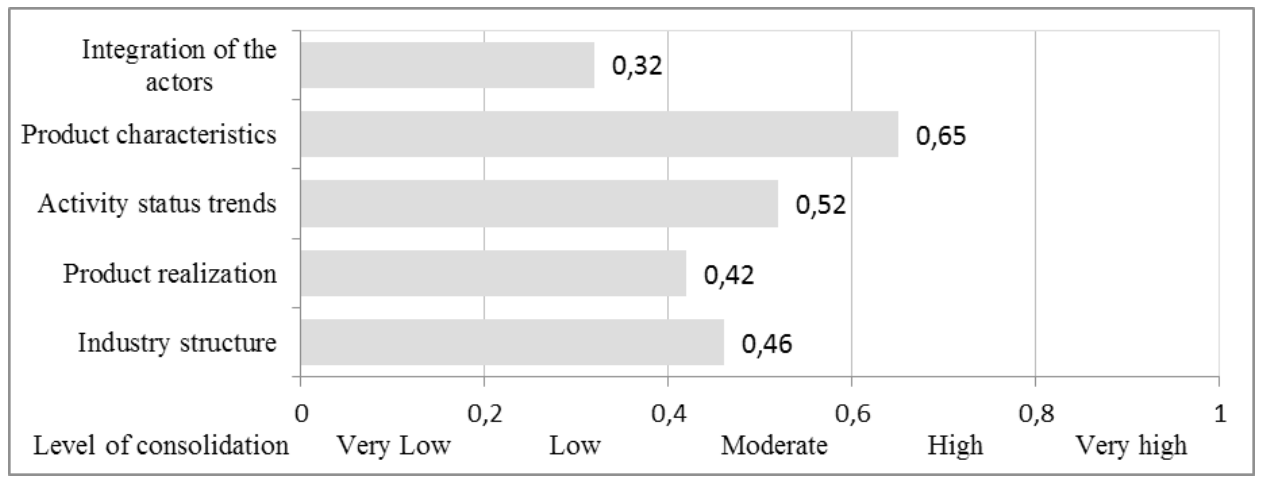

Source: author's elaboration (2011). 
Figure 7 is a disaggregated diagram showing results of performance indicators of competitiveness obtained for the candy industry in San Luis Potosi. It highlights 2 indicators characterized by a very high level of consolidation, 3 showing standard, 10 moderate and 5 - low level of consolidation, and all this in relation to the cluster approach to competitiveness.

Figure 7. Performance levels of the cluster model indicators for the candy industry.

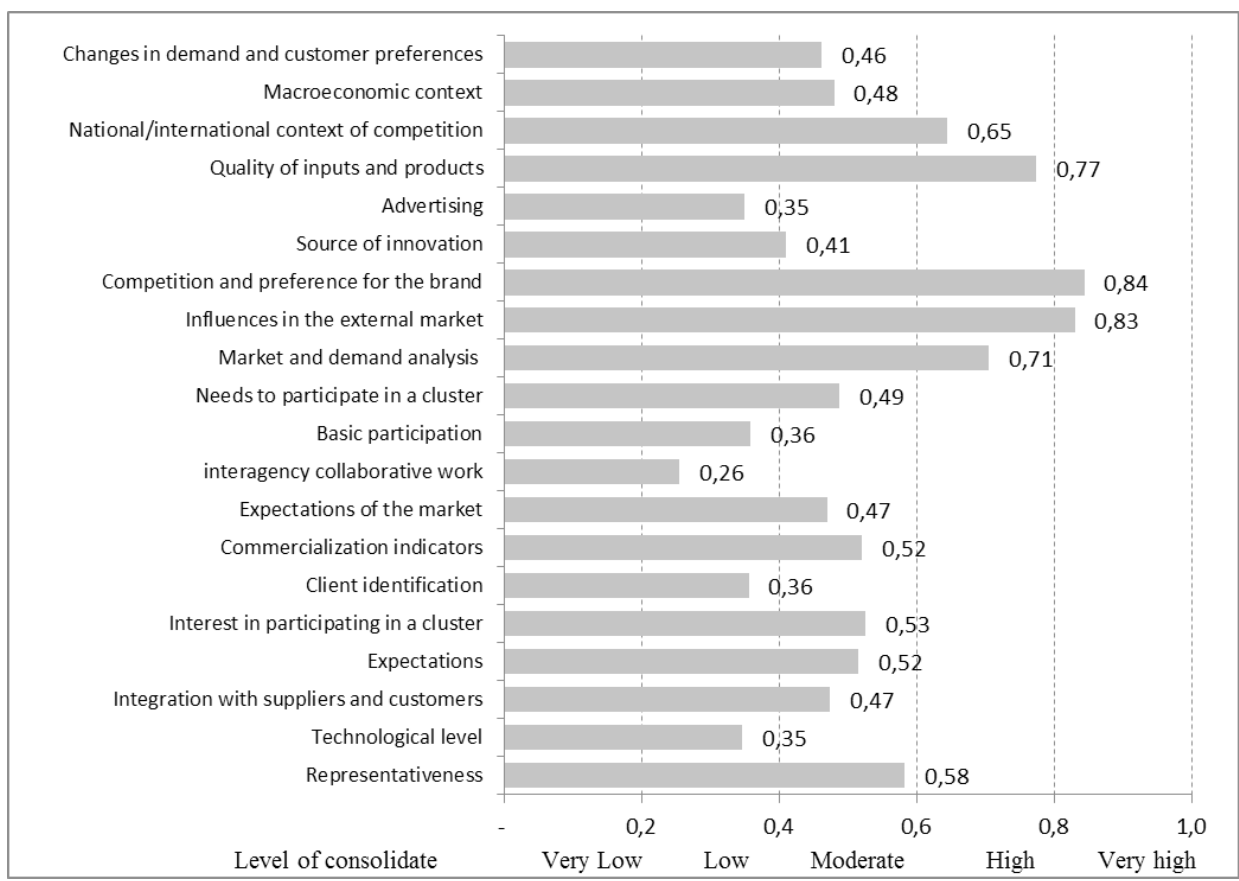

Source: author's elaboration (2011).

The results show the areas of opportunity that exist in the candy industry, making it possible to increase its competitiveness, such as collaborative work of enterprises, improvement of the technological level, investment in advertising or attention to customer requirements. Figure 8 shows the demands that companies identify in the candy industry as priorities in order to be able to economically consolidate and become more productive and competitive. In this figure, it is noteworthy that major claims made by the companies refer to the impact of operating costs, reflecting a constraint to competitiveness, as there is a serious problem of cost competition in the candy industry. 
Figure 8. Critical factors of competitiveness (business requirements).

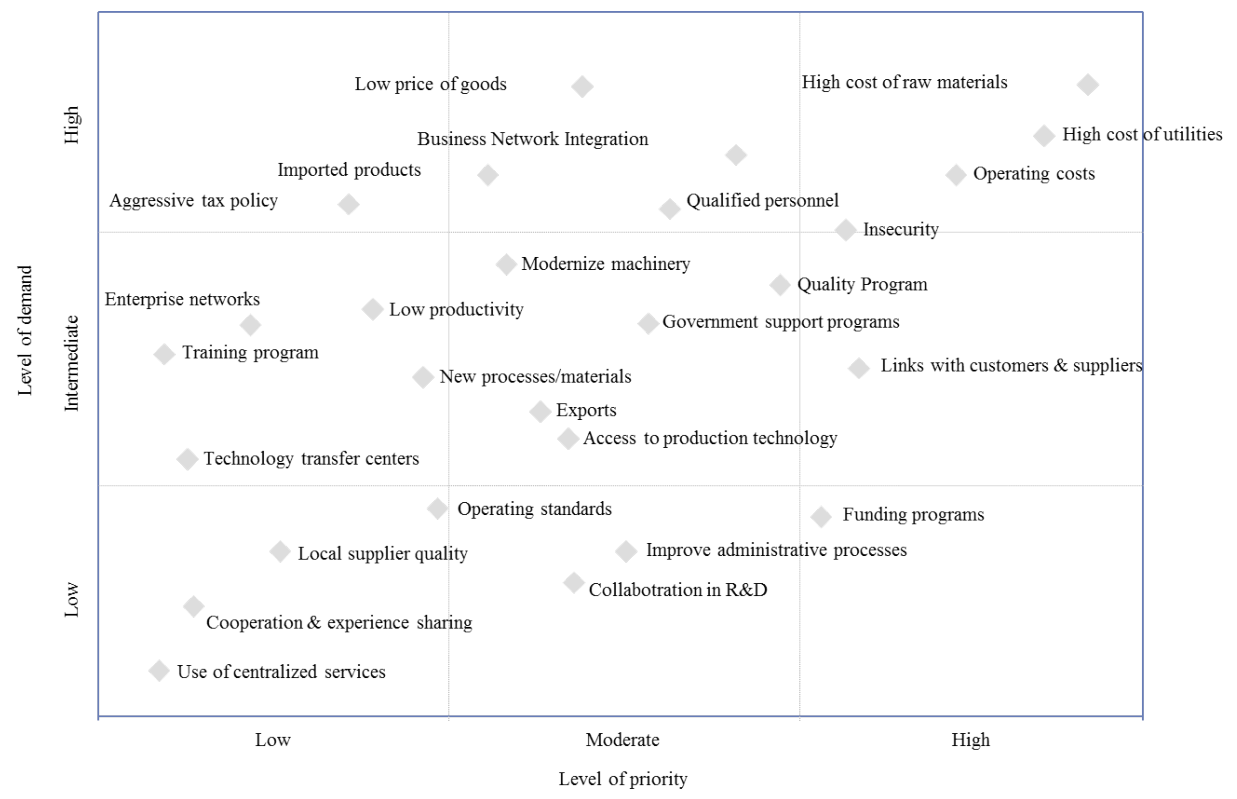

Source: author's elaboration (2011).

The companies forming the candy industry were asked to identify the main needs they considered important to carry out productive activities. These needs were then classified according to priority. They may be broken down into five types according to their importance to businesses: financial support, promotion, production, modernization and coordination, and services. The results show that $68 \%$ of companies identified financial support as their top priority, 58\% mentioned promotion activities, $48 \%$ focused on priorities for improvement in the production system, $45 \%$ of companies referred to modernization as a high priority, while $45 \%$ agreed that coordination between actors and provision of services were the priorities enabling them to be more competitive.

The study of competitive factors observed in the candy industry of San Luis Potosi revealed the following competitiveness related problems in enterprises and the business environment:

- Very high competitiveness problems for operating costs;

- High competitiveness problems for productivity and technological level reported;

- High competitiveness problems for generation of value added and linking of companies;

- Moderate competitiveness problems for provision of production infrastructure and the macroeconomic environment. 
In this sense, the cluster focus stands out as a strategy that, besides supporting the analysis of competitiveness, makes it easier to organizations to use information prioritization in order to present specific propositions and policies.

The effort made by companies to be more competitive requires trust and responsibility when working with suppliers and customers, but when all the efforts of supporting instruments, such as financial institutions, government programs (local, national or international), research centers, institutions of higher education or business centers as well as specific agreements addressing the most pressing demands are eventually carried out, this will pave the way for the successful achievement of objectives.

Considering the study results obtained for the candy industry of San Luis Potosi, where the "integration of the actors" component showed the lowest level of competitiveness, a proposal of economic policy has been provided below, aimed to increase the competitiveness of this industry in the context of a cluster.

Specific actions are presented to improve the link between companies, bearing in mind that collaborative work is very favorable to businesses and that it is through collaboration with related institutions that their operating costs can be reduced, the production process improved, the product positioned and their goals accomplished with greater certainty and in a shorter time.

\section{Strengthening competitiveness by linking businesses}

Table 9 shows specific actions proposed to companies operating in the candy industry to become more competitive. The information provided has been divided into 4 segments in order to differentiate between individual linkage types strengthening companies: linking aimed at facilitating access to financing, services associated with research and technology transfer, linkage related to industry and business organizations, and linkage that would exert positive influence across government levels. As a follow-up, Table 10 shows 17 actions identified as strategic, classified by type, priority level and runtime needed to be implemented.

Table 10. Policies designed to strengthen the candy industry in San Luis Potosí. "Integration of the actors" component.

\begin{tabular}{|c|c|c|c|c|}
\hline \multicolumn{5}{|c|}{ Access to funding programs } \\
\hline Action & Institutions & $\mathrm{T}$ & $\operatorname{Pr}$ & $\mathrm{Lt}$ \\
\hline $\begin{array}{l}\text { Promote the establishment of agreements } \\
\text { with financial institutions for preferential } \\
\text { credit conditions. }\end{array}$ & $\begin{array}{l}\text { NAFIN, FONAES, BANCOMEXT, } \\
\text { SIFIDE, Commercial banking }\end{array}$ & $\mathrm{F}$ & $\mathrm{L}$ & $S$ \\
\hline $\begin{array}{l}\text { Support programs for technological devel- } \\
\text { opment. }\end{array}$ & $\begin{array}{l}\text { IES, CIATEQ, CONACYT, COPO- } \\
\text { CYT, UDIT, ADIAT, INIFAP }\end{array}$ & $\mathrm{I}$ & M & M \\
\hline
\end{tabular}


Relationship between research centers and HEI Action Institutions
$\mathrm{T} \quad \operatorname{Pr} \mathrm{Lt}$

Program support, assistance, technological IES, CIATEQ, CONACYT, COPO-

development and innovation of companies and research centers.

CYT, UDIT, ADIAT, INIFAP, SI- I $\quad \mathrm{L}$ S FIDE, SEDECO, BANCOMEXT

Signing cooperation agreements with IES to improve business efficiency and quality of products.

IES, CONACYT, CIATEQ, COPOCYT, NAFIN

I $\quad \mathrm{L} \quad \mathrm{M}$

IES, UASLP-FI Alim. $\quad$ M M M

gree program for food engineering career specialized in candies and chocolate.

Perform cooperation agreements with IES to consolidate production standards in business.

Formalize agreements with IES and CTT IES, CIATEQ, CONACYT, COPOfor the practice of innovation in goods and services components.

Diploma in production of candy and chocolate.
CYT, UDIT, ADIAT, INIFAP, SI- I $\quad \mathrm{H} \quad \mathrm{M}$ FIDE, SEDECO, BANCOMEXT

IES, SE, SEDECO, CANACINTRA $\quad$ M $\quad M \quad M$

Business network integration

\begin{tabular}{ccccc} 
Action & Institutions & $\mathrm{T}$ & $\mathrm{Pt}$ \\
\hline
\end{tabular}

Establishment of a corporate food sector in SLP.

CANACINTRA, CCE

M $\quad \mathrm{L} \quad \mathrm{M}$

Holding events to promote business for experience sharing.

CANACINTRA, CANACO, SEDECO, SE

$M \quad M \quad S$

Encourage companies to register with CANACINTRA, CANACO, SEDECO, business associations.

SE, SF: DRPF, SIEM

M $\quad \mathrm{L} \quad \mathrm{S}$

Design and build information instruments CANACINTRA, IES, CANACO,

useful for companies operating in the sec-

tor.

SEDECO, CITY COUNCIL, CCE, M $\mathrm{L}$ S SIEM

Promote participation of enterprises in the

sector related events (fairs, conferences, expos, etc.).

SEDECO, CANACINTRA, CANACO, CCE, SIFIDE

$M \quad M \quad S$

Promoting partnerships with related industries for the use of centralized services.

CANACINTRA, CANACO, SEDECO M L L

Need to integrate with government

Action

Institutions

T $\operatorname{Pr} \mathrm{Lt}$ 
Promote the provision of support programs delivered by public sector companies in the food sector.

Fiscal support program for the consolidation of companies in the candy and chocolate industries.

Implement the program of support for organizations, formalization and legal advice to SMEs of the industry.
SEDECO, NAFIN, FONAES, FIRA,

$$
\text { SE, CONACYT, COPOCYT }
$$

M M M

SF: DRPF, NAFIN, FONAES, FIRA, SE, CONACYT, COPOCYT

F $\quad \mathrm{H}: \mathrm{M}$

SEDECO, CANACINTRA, CANACO, CRECE, MEXICO Emprende, S L S COMPITE, STyPS

$\mathrm{T}=$ Type $(\mathrm{M}=$ Modernization; $\mathrm{I}=$ Innovation; $\mathrm{S}=$ Support services; F=Financing $)$

$\operatorname{Pr}=$ Priority $(\mathrm{H}=$ High, $\mathrm{M}=$ Moderate, $\mathrm{L}=$ Low $)$

Lt $=$ Lead Time $(\mathrm{S}=$ Short, $\mathrm{M}=$ Medium, $\mathrm{L}=$ Long $)$

Source: author's elaboration.

For description of institutions, see the annex.

A short-term period does not exceed 2 years and is dependent on one or two specific institutions for the sake of completion. A medium-term period is between 2 and 6 years. A long-term period is more than 6 years, and it is the time required for policy implementation and completion of other actions. It also relies on the intervention of multiple institutions.

\section{Cluster policy recommendations}

The actions outlined here represent a response to the needs identified in the candy industry and seek to promote competitiveness of these actions by strengthening the economic importance of the region, reinforcing the production structure, improving the product quality as well as diversifying and expanding the market for their products.

In light of similar properties displayed by the entire candy industry in Mexico, and particularly the proportion of small and medium-size enterprises and the quality of local products (see Table 8), it is possible to extend the recommendations provided for the industry in San Luis Potosi, perceiving linkage with other major states such as Jalisco, Puebla, Distrito Federal and Estado de Mexico as a competitive strategy.

The contribution of this research is to highlight the value of collaborative work in enterprises as a strategy to achieve your goals in less time, less cost, less effort and greater certainty. The set of proposed strategies allows companies to become more competitive in the medium and long term.

Finally, we must recognize that the competitiveness strategy must be accompanied by actions to consolidate other competitive factors of the proposed model, as Industry structure, product characteristics, product realization and Activity status trend.

Productivity may trigger job reductions in a company due to optimization of resources or technology implementation, but absence of competitiveness can lead to closing of businesses, and consequently to complete liquidation of all jobs. 


\section{Bibliography}

Annoni P. and Dijkstra (2013) L. EU Regional Competitiveness Index. RCI 2013. Joint Research Centre of the European Commission

Aranguren, Mari Jose, Susana Franco, Christian Ketels, Asier Murciego, Mikel Navarro, James R. Wilson. (2010). Benchmarking Regional Competitiveness in the European Cluster Observatory. European Commission.

Bronisz, Urszula, Wim Heijman, Andrzej Miszczuk (2008). Regional competitiveness in Poland: Creating an index. Jahrbuch fur Regionalwissenschaft 28: 133-143.

Cabrero Mendoza, Enrique (2012) Retos de la competitividad urbana en México. CIDE.

Camagni, R. (2002). 'On the Concept of Territorial Competitiveness: Sound or Misleading?', Urban Studies, 39 (13), 2395-2411.

Dijkstra L., Annoni P. (2013). EU Regional Competitiveness Index RCI 2013. Joint Research Centre of the Economist Intelligence Unit (EIU) 2012, Hot Spots: Benchmarking Global City Competitiveness, viewed 12 March 2013, <http://www.citigroup.com/citi/ citiforcities/pdfs/hotspots.pdf $>$.

Dijkstra, L., Annoni, P., \& Kozovska, K. (2011). A new regional competitiveness index: Theory, Methods and Findings. European Union Regional Policy Working Papers, n. $02 / 2011$

European Competitiveness Report 2013: Towards knowledge driven reindustrialization. European Commission

Europe 2020 Poland. Fueling Growth and Competitiveness in Poland: Through Employment, Skills, and Innovation

European Competitiveness Report 2014. Helping Firms Grow. European Union.

Eurostat: http://epp.eurostat.ec.europa.eu

Global Manufacturing. Competitiveness Index (2010). Deloittte.

Grudzewski W., Hejduk I., 2008

IMD World Competitiveness Yearbook 2013. Published by the World Competitiveness Center.

Índice de Competitividad Sistémica de las Entidades Federativas ar, 2012

Índice de Competitividad Sistémica de las Ciudades Mexicanas ar., 2013

INEGI. Censos Economicos 2009

Institute for Management Development (IMD) World Competitiveness Yearbook 2014

ITESM. (2012). Observatorio Estratégico Tecnológico (Technologic Strategic Observatory). Mapas de Oportunidades. Clusters actuales según entidad en Mexico.

Overview. World Bank Human Development and Private and Financial Sector Development Departments. March 2011.

Marshall, A. (1919). Industry and Trade. Londres: Macmillan

Martin, Ronald L. (2005). A Study on the Factors of Regional Competitiveness. A draft 
final report for The European Commission. Directorate-General Regional Policy. University of Cambridge.

Meyer, Jörg -Stamer. (2008). Systemic Competitiveness and Local Economic Development. Duisburg.

Natalie Wojtarowicz Measuring City Competitiveness: Emerging Trends and Metrics. Working Paper Series, May 2013. The Future Cities Institute

Nollen, S 2011, 'Improving City Competitiveness: City Management and the Business Climate', Policy/Practice Note 1 for the World Bank Institute, viewed 29 March 2013.

Planning Commission of India. 2012. Twelfth Five Year Plan 2012-17. Available at http:// planningcommission.nic.in/plans/planrel/fiveyr/welcome.html.

Porter, M. 1990. The Competitive Advantage of Nations. New York: The Free Press.

Porter, M. E. (2008). On Competition. A Harvard Business Review Book.

ProMéxico (2011). "Processed food industry". http://mim.promexico.gob.mx/wb/mim/ agroalimentaria_perfi 1_del_sector in February 2013

Raluca, Aniela (2012). Model for Evaluating Regional Competitiveness Regarding Foreign Investment Attraction.

Rostow, W. W. 1960. The Stages of Economic Growth, a Non-Communist Manifesto. Cambridge: University Press.

Sala-i-Martín X., J. Blanke, M. Drzeniek Hanouz, T. Geiger, I. Mia, and F. Paua. 2007. "The Global Competitiveness Index: Measuring the Productive Potential of Nations." The Global Competitiveness Report 2007-2008. Hampshire: Palgrave Macmillan. 3-50.

Schumpeter, J. 1942. Capitalism, Socialism and Democracy. New York: Harper \& Row; 3rd Edition, 1950.

Sirkin, Harold L., Michael Zinser, Justin R. Rose (2014). The Shifting economics of global manufacturing. How cost competitiveness is changing worldwide. The Boston Consulting Group. August 2014.

Smith, Adam (1776). An inquiry into the Nature and Causes of the Wealth of Nations. W. Strahan \& T. Cadell. England.

Sölvell, Örjan (2008). Clusters Balancing Evolutionary and Constructive Forces. First edition, Ivory Tower Publishing, Stockholm, Sweden.

Sölvell, Ö., Lindqvist, G., \& Ketels, C. (2003). The Cluster Initiative Greenbook. Stockholm: Ivory Tower. Retrieved from http//: www.cluster-research.org.

The Council on Competitiveness, (2011). Report Ingnite 1.0. Voice of AmericanCEOs on Manufacturing Competitiveness.

The 2013 Global Manufacturing Competitiveness Index. Deloitte Touche Tohmatsu Limited (Deloitte) and The U.S. Council on Competitiveness.

The Global Competitiveness Report 2013-2014

Weber, A. 1909. Theory of The Location of Industries (translated by C.J. FREIDRICH, 1929). Chicago: University of Chicago Press. 


\section{Annex}

Table 11 Institutional infrastructure to support business development

\begin{tabular}{|c|c|}
\hline Acronym & Description \\
\hline FONAES & National Fund Business in Solidarity \\
\hline FIRA & Trust Funds to Agriculture \\
\hline NAFIN & Nacional Financiera \\
\hline BANCOMEXT & Foreign Trade Bank \\
\hline SEDECO & Ministry of Economic Development of San Luis Potosi \\
\hline SIFIDE & System of Finance for Development \\
\hline STyPS & Ministry of Labour and Social Welfare \\
\hline ICAT & Training Institute for Work \\
\hline SEER & Regular State Education System \\
\hline SE & Ministry of Economy \\
\hline SIEM & Mexican Business Information System \\
\hline COMPITE & National Committee for Productivity and Technological Innovation AC \\
\hline CCE & Business Coordinating Center \\
\hline IPAC & Industrials Potosinos AC \\
\hline CANACO & National Chamber of Commerce \\
\hline COPARMEX & Employers Confederation of the Mexican Republic \\
\hline CONCAMIN & Confederation of Industrial Chambers of the United Mexican States \\
\hline COMCE & Mexican Business Council for Foreign Trade, Investment and Technology, AC \\
\hline AMB & Mexican Association of Banks \\
\hline FUNDEMEX & Business Foundation of Mexico AC \\
\hline CANACINTRA & National Chamber of the Transformation Industry \\
\hline CNEC & ational Chamber of Consulting Firms \\
\hline APERIAC & Executives Potosina Association of Industrial Relations, AC \\
\hline CRECE & Regional Center for Business Competitiveness. \\
\hline CTT & Technology Transfer Centers \\
\hline IPICYT & Potosino Institute of Scientific and Technological Research \\
\hline COPOCYT & Potosino Council for Science and Technology \\
\hline CONACYT & National Council for Science and Technology \\
\hline IES & Higher Education Institutions \\
\hline UASLP-I.Alim. & Autonomous University of San Luis Potosi. Food Engineering \\
\hline CIATEQ & Advanced Technology Center \\
\hline INFOTEC & Fund of Information and Documentation for Industry \\
\hline FCCyT & Scientific and Technological Consultative Forum \\
\hline UDIT & Unit Development and Technological Innovation \\
\hline ADIAT & Association of Directors of Applied Research and Technology Development \\
\hline SF: DRPF & Ministry of Finance: Revenue Management and Fiscal Policy \\
\hline SEMARNAT & Ministry of Environment and Natural Resources \\
\hline SEGAM & Ministry of Ecology and Environmental Management \\
\hline CFE & Federal Electricity Commission \\
\hline $\mathrm{CNA}$ & National Water Commission \\
\hline
\end{tabular}




\begin{tabular}{ll} 
CEA & State Water Commission \\
SCT & Ministry of Communications and Transport \\
JEC & State Roads Commission \\
INVIES & Housing Institute of the State of San Luis Potosi \\
\hline SEDUVOP & Ministry of Urban Development, Housing and Public Works \\
\hline INTERAPAS & Inter Agency Water Services and Wastewater \\
SSP & Ministry of Public Security \\
PGJ & Attorney General \\
\hline
\end{tabular}

Source: author's elaboration. 